\title{
A trend study in the stratification of social media use among urban youth: Chile 2009-2019
}

\author{
TERESA CORREA \\ Universidad Diego Portales, Chile
}

SEBASTIÁN VALENZUELA

Pontificia Universidad Católica de Chile, Chile

Millennium Institute for Foundational Research on Data (IMFD), Chile

\begin{abstract}
This trend study describes changes and continuities in the stratification of usage of Facebook, Twitter, Instagram, and WhatsApp in Chile between 2009-2019 - the decade that witnessed the rise of social media. Using the Youth, Media and Participation Study - a probabilistic survey conducted on an annual basis among 1,000 individuals aged 18 to 29 living in the three largest urban areas in Chile $(\mathrm{N}=10,518)$-we analyze how frequency of use and type of activities conducted on social media has varied over time along socioeconomic status, gender, and age cohort. Instead of a uniform trend towards less (or greater) inequality, the results show that each platform exhibits a unique dynamic. For instance, whereas SES-based inequality in frequency of use has decreased on Facebook over time, it has remained stable on WhatsApp and increased on Twitter and Instagram. In addition, significant differences in the likelihood of conducting different activities (e.g., chatting, commenting news, sharing links) remained across groups, even on platforms such as Facebook where frequency of use has equalized over time.
\end{abstract}

Teresa Correa: teresa.correa@udp.cl Date submitted: 2021-01-07

Copyright (C) 2021 (Teresa Correa, Sebastián Valenzuela). Licensed under the Creative Commons Attribution Non-commercial No Derivatives (by-nc-nd). Available at: http://journalqd.org 
Keywords: social media, Facebook, WhatsApp, Twitter, Instagram, Chile, trend study, representative survey, digital inequality.

In the last decade, social media have become ingrained in our daily lives and has revolutionized the personal, social, political and economic spheres. Although the term is widely used to encompass different tools and platforms, the definition of what constitutes social media is contested (McCay-Peet \& Quan Haase, 2017). In the Spanish language we have a similar dilemma. We loosely talk about "redes sociales" to include platforms with diverse affordances, uses and implications.

Perhaps, the lack of consensus in the definition of social media stems from their relative novelty and ever evolving nature. We still need to better understand them. How different or similar are they? Who uses them and for what purposes? Have these trends varied over time? To what extent can we generalize from one platform to the others? To address some of these questions, this study describes changes and continuities in how the usage of Facebook, Twitter, Instagram and WhatsApp among young adults has evolved in Chile between 2009 and 2019, the decade the witnessed the rise of social platforms. Particularly, using the Youth, Media and Participation Study - a face-to-face probabilitybased survey conducted on an annual basis among people aged 18 to 29 in Chile-we seek to describe how frequency of use and type of activities conducted on social media has varied over time along socioeconomic status (high, middle, low), gender (binary), and age cohort (18-24 vs. 25-29).

\section{Defining Social Media}

Despite the widespread use of the term "social media" in the last decade, there is still no agreed-upon definition. Based on a review of contemporary conceptualizations, McCay-Peet and Quan Haase (2017) proposed a broad demarcation of the term to purposefully include several platforms with social interactions as an integral part: 
Social media are web-based services that allow individuals, communities and organizations to collaborate, connect, interact and build community by enabling them to create, co-create, modifies, share, and engage with usergenerated content that is easily accessible (p. 17)

Although this general definition is broader than previous ones, which mostly focused on social network sites (SNSs) such as Facebook, Twitter and MySpace (e.g., Ellison \& boyd, 2013), current definition attempts try to distinguish traditional media from these newer media that are essentially social. They also seek to be more inclusive and flexible in the platforms that fall under the umbrella of social media to capture this rapidly evolving landscape of online social platforms. If previous demarcations mostly focused on SNSs, current definitions would consider SNSs as one type of social media but also include several other platforms including WhatsApp (Boczkowski et al., 2018; Karapanos et al., 2016; Pang \& Woo, 2020). Finally, they seek to pave the way for more parsimonious theory-building. However, the level of social interaction and types of uses, perceptions, and implications vary over time and across different platforms (Waterloo et al., 2018; Blank \& Lutz, 2017; Litt \& Hargittai, 2016).

In fact, Papacharissi (2015) asserts that any attempt of understanding social media should be "temporally, spatially, and technologically sensitive" (p. 1). In response to this dynamic character, affordances have become an increasingly used theoretical concept to understand social media platforms. Originally, affordances were defined as "the perceived and actual properties of the thing... that determine just how the thing could possibly be used" (Norman, 1988, p. 9). Despite being conceptualized in various ways (Bucher \& Helmond, 2018), current work on digital technologies and social online platforms follow a more relational approach that captures the interaction between the materiality and people's agency by focusing on the device and the social construction of it (Ellison \& Vitak, 2015; Pavez \& Correa, 2020). Therefore, when studying social platforms, we have to focus not 
on the device or application but on "the relationship between the people and the materiality of the things with which they come in contact" (Treem \& Leonardi, 2012, p. 146).

Much research has tried to explain the affordances of social media as a unitary concept, that is, affordances that are applicable across platforms. However, it is just as important to understand the differences and similarities among platforms. Each platform's features can be seen as "communicational actors" (Langlios, 2014) because they afford different meanings, expectations and practices for different types users, including endusers, developers and advertisers (Bucher \& Helmond, 2018).

Research on social media has categorized different affordances, such as visibility, editability, association (e.g., Treem \& Leonardi, 2012). For instance, WhatsApp, was born in 2009 as a mobile instant messaging service with high levels of privacy. Over time, it has evolved into an encompassing communication space that can also be accessed through the computer, is deeply integrated into people's daily life, and is necessary to contact and manage individual and groups of friends, family and work as well as share information, news, humor and mobilizing content among people's social networks (Boczkowski et al., 2018; Pang \& Woo, 2020). Facebook offers the possibility to regulate privacy and can be used to connect with strong-tie networks such as family and friends (Valenzuela et al., 2018).

Instagram is an app that uses images as venues for communication, with most users posting selfies. Many users spend time and focus to present an online image that gets praise and likes (Huang \& Su, 2018). Instagram users can adjust the levels of privacy but the default setting is public and most people follow public accounts (Waterloo et al., 2018). Twitter is a microblogging site that allows unidirectional or asymmetrical connections, where reciprocal approval is not needed to follow other users. Although Twitter networks can include strong ties such as family and friends, the application is set to follow people that users do not know personally-the so-called weaker ties-including celebrities, journalists, politicians, commentators and news organizations (Valenzuela et al., 2018). In 
response to its stagnant user growth, the platform has changed some features such as the favorite feature and introduced an algorithmic timeline, which has led to different reactions, meanings and interpretations by users (Bucher \& Helmond, 2018).

Because these platforms as well as people's contexts and needs vary temporally and spatially, it is relevant to understand how the interaction between individuals and these social online platforms varies over time and contexts.

\section{The Digital Context in Chile}

The rise of social media use in Chile has coincided with a rise in social movements and protests, particularly among young people in urban areas (Somma \& Medel, 2019). The peaks in mobilization have been 2011 - with vast street manifestations over education and environmental issues - and October 2019-when civil riots erupted against a raise in the metro's subway and, more generally, against poor pensions, increased cost of living and socioeconomic inequality. Despite being regarded as a high-income Latin American country by organizations such as the OECD, Chile has high levels of socioeconomic inequality, on par with developing countries and many South American neighbors (Rucks, 2018). According to World Bank data (2021), Chile's most current Gini index is 44.4, similar to Ecuador (45.4), Peru (42.8), higher than Argentina (41.4) and Uruguay (39.7) and lower than Brazil (50.4) and Colombia (50.4). In most developed countries, Gini coefficients hover around 27 to 30 points (except the United States, with 41.1).

Due to long-standing policies in the domain of information and communication technology since the early 1990s (Kleine, 2013), Chile is one of the leaders in internet access and usage in the region (Rojas \& Poveda, 2018). According to national figures, home internet access has increased from $70.2 \%$ in 2015 to $87.4 \%$ in 2017 (Subtel, 2017), driven mostly by a surge in mobile connections and smartphones. A comparative survey revealed that Chile has similar levels of smartphone penetration with Canada and United Kingdom and surpasses Germany, France and all the Latin American countries included in 
the study (Pew Research Center, 2016). The quality of mobile connections, in terms of speed, is among the highest in Latin America but lower than developed countries (Open Signal, 2017). Social media penetration levels are also the highest in the region (Hilbert et al., 2017).

The first social platforms to become popular in Chile were Facebook and Twitter, which took off in 2008. WhatsApp came next, in 2012, and Instagram in 2014. Currently, these four social platforms are the most used and influential. Facebook and WhatsApp are used by over $80 \%$ of internet users, followed by Instagram (55\%) and Twitter (31\%) (Newman et al., 2020). Because social inequalities are the most relevant cleavages in Chile, this study focuses on the evolution of the four most popular social media platforms along enduring digital gaps: SES, gender and age differences.

\section{Data}

The data employed in this longitudinal study were obtained from the Youth, Media and Participation project, led by the School of Journalism at Universidad Diego Portales (UDP) and the professional polling firm Feedback. Since 2009, the project conducts annual face-to-face surveys among representative samples of individuals aged 18 to 29 living in Chile's three largest urban areas (Greater Santiago, Valparaíso-Viña del Mar, and Concepción-Talcahuano), which represent $68 \%$ of urban youth in the country (INE, 2017). Urban areas in Chile are defined as "group of concentrated households with more than 2,000 inhabitants or between 1,000 and 2,000 inhabitants where more than $50 \%$ of people" are dedicated to non-extractive economic activities, such as manufacturing and services (INE, 2018).

Each year a fresh sample is drawn, but the sampling frames and procedures are the same: a multistage probability sample stratified by urban area. In each urban area, the sample is distributed proportionally by communes and blocks. For each randomly selected block, five households are randomly selected. In each household an adult aged 18 to 29 is 
randomly chosen for interviewing. If a household does not have adults aged 18 to 29 , it does not meet the selection criterion and another one is randomly selected. Given the faceto-face nature of the surveys and its focus on urban areas, response rates are relatively high. Using the AAPOR (2016) RR1 method, they have ranged between $60 \%$ and $80 \%$. The sample sizes are about 1,000 young adults (see Table 1 for fieldwork dates and exact sample sizes). Original data and questionnaires are available (in Spanish) at https://ciclos.udp.cl/proyectos/encuesta-de-jovenes-participacion-y-medios/

Table 1 : Fieldwork Dates and Sample Size

\begin{tabular}{llr}
\hline Study year & Field work dates & Sample size \\
\hline 2009 & Sept. 10-26, 2009 & 1,000 \\
2010 & Aug. 27-Sept. 10, 2010 & 1,000 \\
2011 & Aug. 19-Sept. 6, 2011 & 1,014 \\
2012 & July 13-23, 2012 & 748 \\
2013 & Oct. 3-20, 2013 & 1,000 \\
2014 & Nov. 24-Dec. 12, 2014 & 1,000 \\
2015 & Dec. 12, 2015-Jan. 4, 2016 & 1,011 \\
2016 & Nov. 19-Dec. 4, 2016 & 1,012 \\
2017 & Nov. 20-Dec. 15, 2017 & 727 \\
2018 & Nov. 24-Dec. 7, 2018 & 1,006 \\
2019 & Nov. 21-Dec. 15, 2019 & 1,000 \\
& \multicolumn{2}{c}{ Total } \\
\hline
\end{tabular}

\section{Variables}

In what follows, we describe the variables used in the study. Tables with the distribution of these variables over the years are included in the supplementary appendix.

Social media use. To compare general trends in use of social media relative to traditional media, in all survey years respondents were asked the following open-ended question: "On a typical day, on average, how many hours do you spend on the following 
media?" Responses were recorded on a scale ranging from 0 to 24 . The list of media outlets considered included: broadcast TV networks, cable TV networks, radio, internet portals, print newspapers and magazines, online news websites, and social platforms such as Facebook and Twitter (the latter asked with a single item). Responses to the individual items were then combined into five media categories: television, radio, online (excluding social), print, and social.

To compare usage of specific platforms, we relied on a different set of questions than the ones used for traditional media. Specifically, we measured the proportion of registered users as well as frequency of use. Respondents were asked whether they have an account on Facebook, Twitter, Instagram (asked from 2013 onwards), and WhatsApp (asked from 2014 onwards). Among those who had an account, they were asked how often they used it using the following response scale: (1) "once a month or less"; (2) "two or three times a month"; (3) "once a week"; (4) "at least three times a week"; (5) "every day, once a day"; and (6) "every day, more than once a day". Because someone who uses a platform two times a week would neither chose (3) nor (4), we combined these two categories into a new one: "one to six times a week". Also, to maintain sample size, we added the category "never" to include respondents who are not registered users. In the statistical analyses, we followed Guess et al. (2019) and converted this ordinal measure to a per-day numeric variable so that we could treat it as if on an interval or ratio scale. Specifically, we translated response categories as follows: "never" to 0 , "once a month or less" to $1 / 30$, "two or three times a month" to $3 / 30$, "one to six times a week" to $6 / 7$, "every day, once a day" to 1 , and "every day, more than once a day" to 3 .

We also assessed specific activities conducted over social media. First, to measure social platforms as information sources, respondents were asked: "On a typical day, on average, how many hours do you spend watching, reading or listening to news on social network sites such as Facebook, Twitter and other platforms?" Responses were recorded on a scale ranging from 0 to 24. Second, the surveys measured with separate items whether users of Facebook and Twitter linked to other content, chatted with users, and shared 
political opinions. More specifically, Facebook users were asked whether they engage in the following activities on an average week: (a) share links to other content (asked between 2009 and 2017); (b) chat with other users (asked between 2009 and 2015); and (c) express an opinion about political or public affairs (asked between 2011 and 2017). The same items were repeated for Twitter users: (a) link to articles (asked between 2010 and 2017); (b) chat or talk with other users (asked between 2010 and 2015); and (c) express an opinion about political or public affairs (asked between 2011 and 2017). Unfortunately, the surveys did not measure these activities for Instagram and WhatsApp.

Sociodemographics. We estimated trends in social media use across three sets of sociodemographic variables. Socioeconomic status (SES) was gauged using an adaptation of the European Society for Opinion and Marketing Research (ESOMAR) criteria, which combines educational attainment with goods and services at home. Using this classification, a categorical variable was created, with $1=$ higher SES (ESOMAR groups, A, B, and C1), 2 = middle SES (groups C2 and C3), and $3=$ lower SES (groups D and E). Using the respondent's age in years at the time of the survey, we classified the sample into two groups: respondents aged 18 to 23 , and those aged 24 to 29 . This cutoff was chosen based on the literature on socialization, which suggests that between the ages of 18 and 23 individuals experience the end of school, university (when it corresponds), the right to vote, and first experiences of employment (de Regt et al., 2020). Gender was measured in binary terms, coded as man $(51 \%)$ or woman $(49 \%)$.

Time. To capture temporal trends in the data, we created a counter variable representing survey year, ranging from 1 to 11 . When there was evidence of curvilinear time trends, we also computed a quadratic time trend by squaring the counter variable.

\section{Analytical Strategy}

To describe the stratification of social media use among young people in Chile, we first pooled the independent cross sections surveyed each year. With the pooled data, we 
produced a series of time-series plots and conducted formal tests of differences between groups across time using regression models (Wooldridge, 2001, pp. 128-129). In these regressions, we interacted sociodemographic and time variables, with statistically significant interactions indicating that the effects of SES, gender, or age group on social media use differ significantly over time. For instance, the interaction of age and survey year tests whether age effects are differentiated by period or, conversely, whether period effects are differentiated by age. To correct for differences from population parameters and produce more accurate estimates, all analyses were conducted using a post-stratification weight. All estimations were performed on the statistical package STATA (release 15.1). A copy of the command syntax and data set is available at https://doi.org/10.17605/OSF.IO/2RA5M.

\section{Results}

Before analyzing trends in usage of social platforms between groups, it was important to contextualize the role that social media has played over time among Chilean urban youth compared to traditional media. As shown in Figure 1, between 2009 and 2013, mean time spent on Facebook, Twitter, and other social platforms varied between 1.5 and 2.5 hours per day - about the same time spent on television and radio. Subsequently, social platforms took over as dominant media. Between 2014 and 2019, the mean time spent on these platforms increased to 3.5 hours-almost the same time spent on all other media combined (3.4 hours). The downfall of time spent on television, radio and online media is particularly noteworthy, considering that this period coincides with the rise of popular streaming services in Chile, such as Netflix, Prime Video, and Spotify. With these data, then, it is safe to assume that the media diets of urban youth in Chile between 2009 and 2019 became social media dependent. 


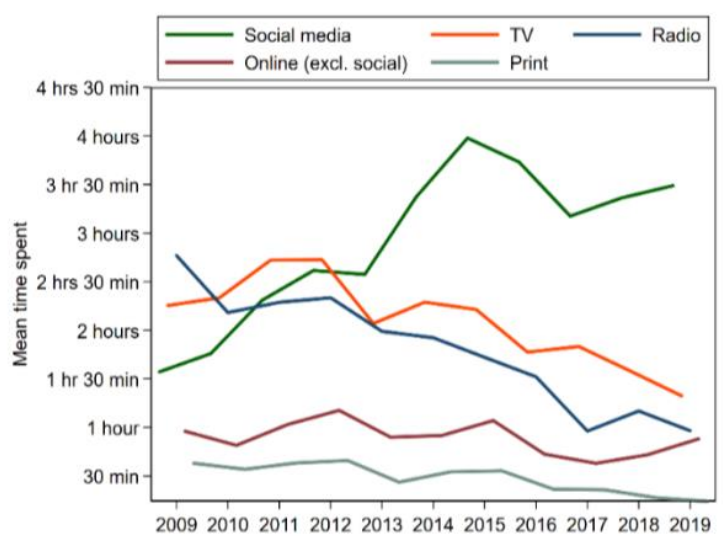

Figure 1: Mean Time Spent on Social Media Compared to Traditional Media

We then compared the popularity of different social platforms, both in terms of registered users and frequency of use (Figure 2). Between 2009 and 2013, Facebook was the leading platform, with a population of users increasing from $73 \%$ to $94 \%$ of the total sample. Twitter peaked in 2012 at 26\%, dropping thereafter until 14\% in 2017 and 2018. In 2019 - the year of the social uprising - nearly $22 \%$ of respondents reported using it. The prominence of Facebook changed when WhatsApp and Instagram made their debut in Chile. Between 2014 and 2019, WhatsApp became a universal platform within the urban $18-29$ cohort, with a user base of $96 \%$ of this population. Instagram, in turn, grew consistently. Between 2013 and 2019, the proportion of registered users increased almost four-fold, from $22 \%$ to $77 \%$.

Trends in frequency of use of each platform mostly mirror the trends in registered users. The proportion of the sample that used Twitter daily remained under $10 \%$ during the whole period. The exception was 2019 , when this figure increased to $12 \%$. The percentage of daily Facebook users grew from $48 \%$ in 2009 to $71 \%$ in 2014, stabilizing thereafter. Likewise, WhatsApp and Instagram had a consistent rate of growth in frequency of use, with a substantial majority of the sample using these applications every day. 

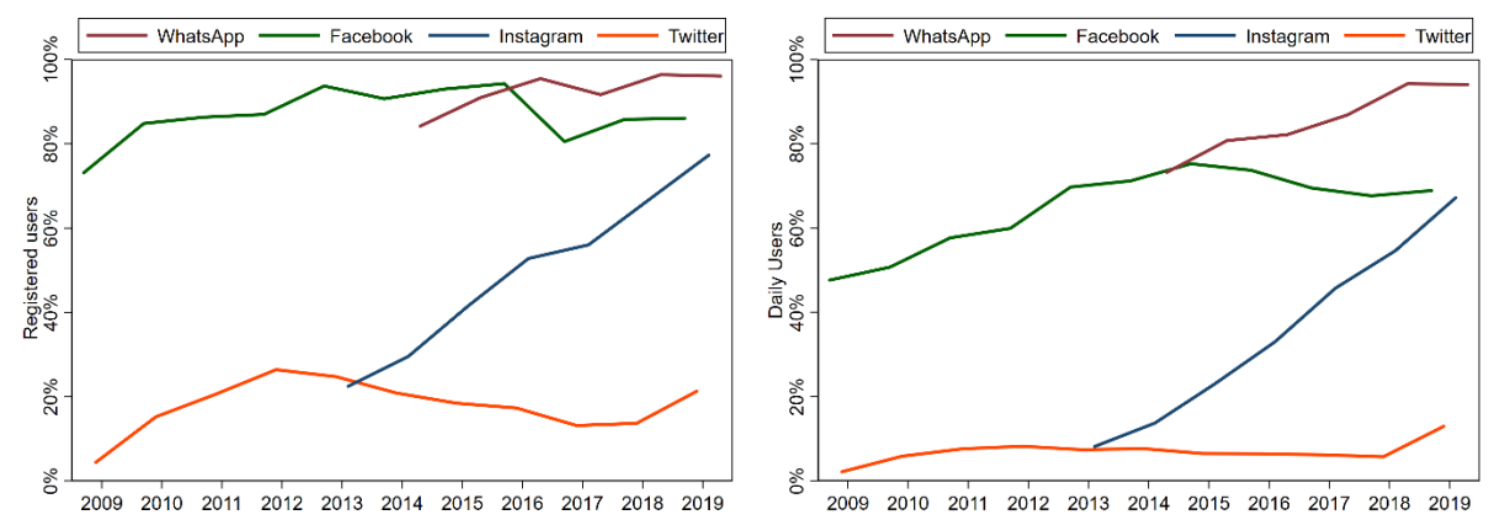

Figure 2: Proportion of Registered Users and Daily Active Users of Social Media

The trends reported thus far summarize the behavior of the total sample but may be masking important variation between groups. To examine this possibility, we now turn to our subgroup analysis. We focus on frequency of social media use instead of the penetration because prior research shows that while access gaps may close between groups, frequency and types of usage gaps are key to understand people's digital media engagement (Büchi et al., 2016; Hargittai \& Hinnant, 2008; van Deursen et al., 2015). In any case, the appendix includes replications of these results with the measure of registered users.

In Figure 3, we break down the proportion of daily users of each platform by socioeconomic status. Instead of a uniform trend towards less (or greater) inequality, the results show that each platform exhibits a unique dynamic. Notably, whereas SES-based inequality in frequency of use decreased on Facebook over time, they seem to have remained stable on WhatsApp and increased in Twitter and Instagram.

To confirm these conclusions based on eyeballing the time series, we regressed frequency of use on SES, survey year, and an interaction of SES and survey year. As shown in Table 2, the interactions between low and middle SES and year of survey were positive and statistically significant in the regression of Facebook. This means the gap in use of 
Facebook between higher SES and both middle and lower SES diminished over time. In contrast, the gap between higher and lower SES respondents in terms of usage of Instagram and Twitter increased slightly - as evidenced by the negative and statistically significant coefficients of the interactions between lower SES and survey year. The same did not occur with WhatsApp, as none of the interactions were statistically significant. Instead, there was a consistent stratification in its use for the whole period, with lower SES respondents using it less frequently than higher SES respondents.

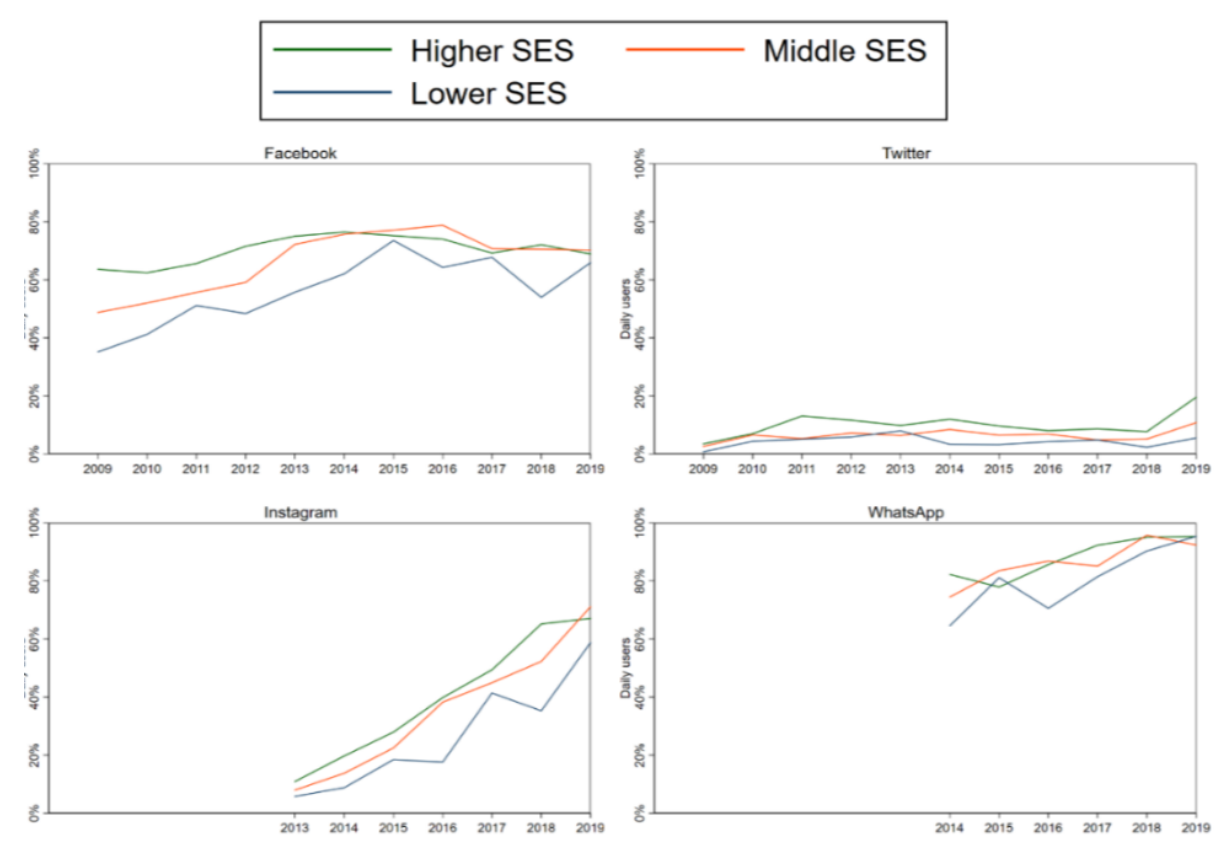

Figure 3: Proportion of Daily Active Users of Social Media by SES 
Table 2: Regressions of Frequency of Use of Social Media by SES

\begin{tabular}{lcccc}
\hline & $(1)$ & $(2)$ & $(3)$ & $(4)$ \\
& Facebook & Twitter & Instagram & WhatsApp \\
\hline Middle SES & $-0.37^{* * *}$ & $-0.08^{*}$ & -0.18 & -0.05 \\
& $(0.07)$ & $(0.04)$ & $(0.15)$ & $(0.20)$ \\
Lower SES & $-0.66^{* * *}$ & $-0.11^{* *}$ & 0.00 & $-0.53^{*}$ \\
Year & $(0.08)$ & $(0.04)$ & $(0.17)$ & $(0.22)$ \\
& $0.04^{* * *}$ & $0.02^{* *}$ & $0.29^{* * *}$ & $0.12^{* * *}$ \\
Middle SES x Year & $(0.01)$ & $(0.01)$ & $(0.02)$ & $(0.02)$ \\
& $0.04^{* * *}$ & -0.00 & 0.01 & -0.01 \\
Lower SES x Year & $(0.01)$ & $(0.01)$ & $(0.02)$ & $(0.02)$ \\
& $0.06^{* * *}$ & $-0.01^{*}$ & $-0.05^{*}$ & 0.04 \\
Constant & $(0.01)$ & $(0.01)$ & $(0.02)$ & $(0.02)$ \\
& $1.67^{* * *}$ & $0.21^{* * *}$ & $-1.13^{* * *}$ & $1.53^{* * *}$ \\
\hline Observations & $(0.06)$ & $(0.04)$ & $(0.12)$ & $(0.15)$ \\
$R^{2}$ & 10,518 & 10,518 & 6,756 & 5,756 \\
\hline
\end{tabular}

Note. Cells report unstandardized OLS regression coefficients with robust standard errors in parentheses. Higher SES is the reference category for SES.

$* \mathrm{p}<0.05, * * \mathrm{p}<0.01, * * * \mathrm{p}<0.001$

Turning now to gender, Figure 4 suggests that different platforms exhibited different trends. Between 2009 and 2012, there were more men than women using Facebook daily, a trend that reversed by 2013 . However, none of the plotted time series of the other platforms show a similar gender gap reversal. The regressions in Table 3 confirm that Facebook has a unique pattern of results. Specifically, there was a significant, positive interaction between gender and survey year, which indicates that over time, women were more likely than men to use Facebook more frequently. For Twitter, Instagram, and WhatsApp, neither the interactions nor the simple main effects of gender were statistically significant. Taken together, these findings suggest little evidence of a gender gap in social media use among urban youth in Chile. 

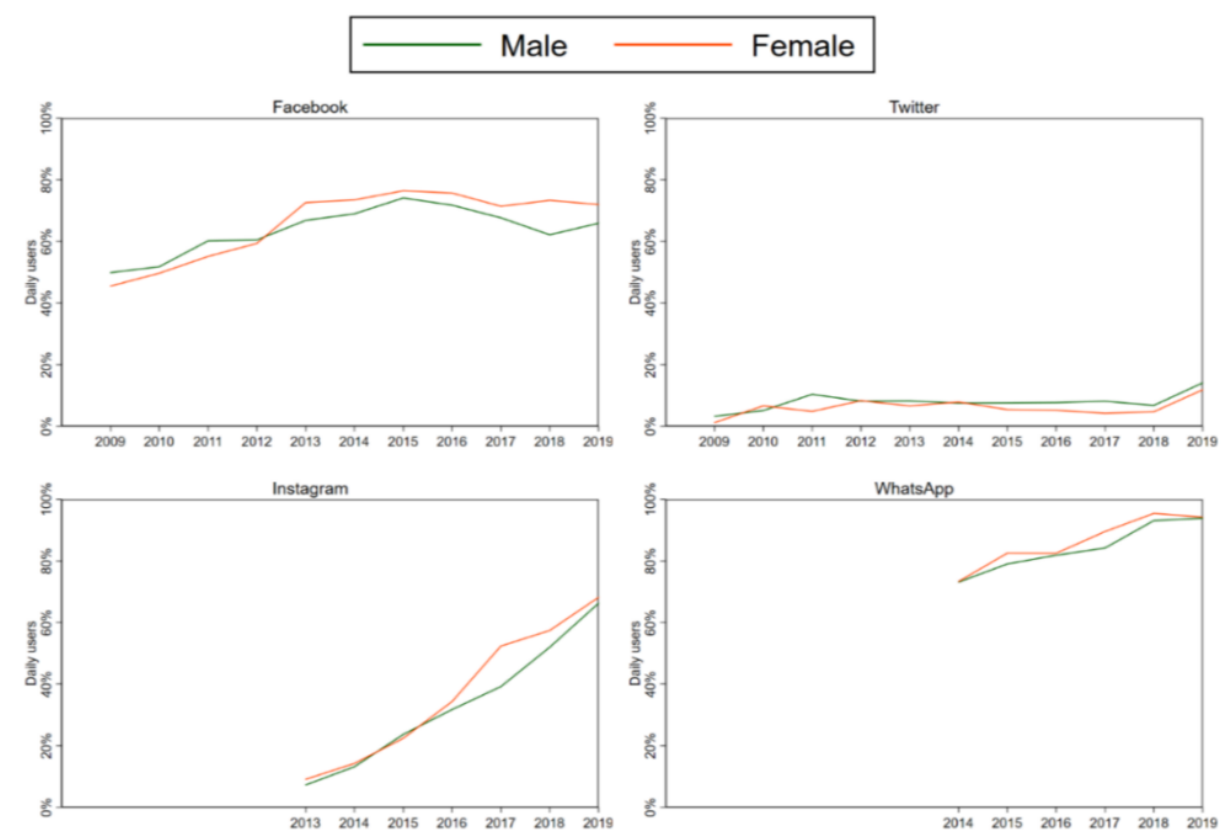

Figure 4: Proportion of Daily Active Users of Social Media by Gender

Table 3: Regressions of Frequency of Use of Social Media by Gender

\begin{tabular}{lcccc}
\hline & $(1)$ & $(2)$ & $(3)$ & $(4)$ \\
& Facebook & Twitter & Instagram & WhatsApp \\
\hline Woman & $-0.15^{*}$ & -0.02 & -0.14 & 0.06 \\
& $(0.06)$ & $(0.03)$ & $(0.12)$ & $(0.17)$ \\
Year & $0.06^{* * *}$ & $0.01^{* * *}$ & $0.27^{* * *}$ & $0.13^{* * *}$ \\
& $(0.01)$ & $(0.00)$ & $(0.01)$ & $(0.01)$ \\
Woman x Year & $0.04^{* * *}$ & -0.00 & 0.03 & 0.00 \\
& $(0.01)$ & $(0.00)$ & $(0.02)$ & $(0.02)$ \\
Constant & $1.38^{* * *}$ & $0.15^{* * *}$ & $-1.21^{* * *}$ & $1.27^{* * *}$ \\
& $(0.04)$ & $(0.02)$ & $(0.09)$ & $(0.12)$ \\
\hline Observations & 10,518 & 10,518 & 6,756 & 5,756 \\
$R^{2}$ & 0.04 & 0.00 & 0.20 & 0.05 \\
\hline
\end{tabular}

Note. Cells report unstandardized OLS regression coefficients with robust standard errors in parentheses.

${ }^{*} p<0.05,{ }^{* *} p<0.01,{ }^{* * *} p<0.001$ 
Compared to gender, age groups made a substantive difference in usage of social media platforms. As shown in Figure 5, for most of the time under study Facebook and Instagram were more likely to be used by college-age respondents than by their older counterparts. Twitter and WhatsApp, in contrast, reported little age differences in usage. However, the age gap in frequency of use varied considerably over time between platforms. As shown in Table 3, while overall younger respondents used Facebook more frequently, the gap diminished over time, as indicated by the positive sign of the interactive term. The opposite trend was observed for Instagram. In this case, not only did younger respondents use the application more frequently, but the age gap in usage increased over time, as indicated by the negative sign of the interaction. In contrast, none of the interactions between age group and year of survey were statistically significant in the regressions of Twitter and WhatsApp. These results mean that no consistent trends were observable in platform usage between age groups. Specifically, both age groups used Twitter and WhatsApp just as often between 2009 and 2019.

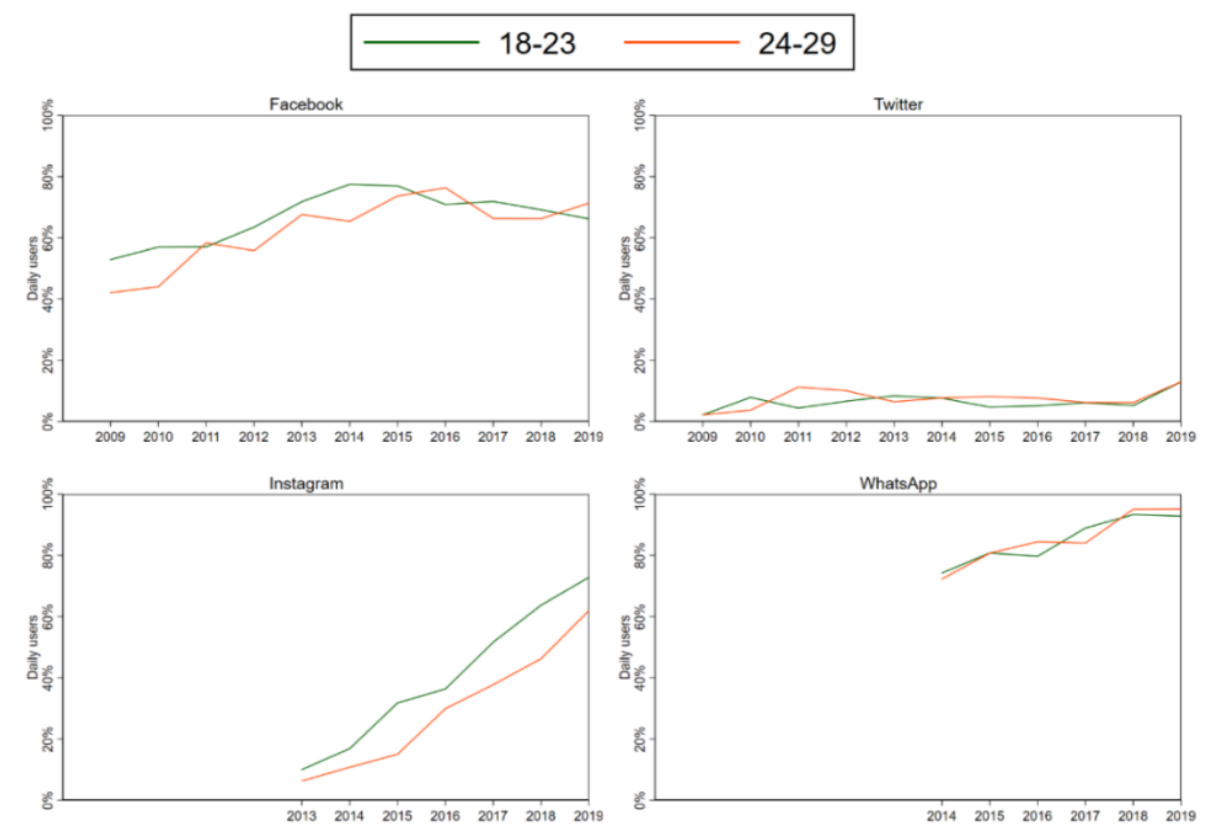

Figure 5: Frequency of Use of Social Media Platforms by Age Group 
Table 4: Regressions of Frequency of Use of Social Media by Age Group

\begin{tabular}{lcccc}
\hline & $(1)$ & $(2)$ & $(3)$ & $(4)$ \\
& Facebook & Twitter & Instagram & WhatsApp \\
\hline Age group 24-29 & $-0.32^{* * *}$ & 0.02 & 0.13 & -0.28 \\
& $(0.06)$ & $(0.03)$ & $(0.12)$ & $(0.17)$ \\
Year & $0.06^{* * *}$ & $0.01^{* * *}$ & $0.31^{* * *}$ & $0.11^{* * *}$ \\
& $(0.01)$ & $(0.00)$ & $(0.01)$ & $(0.01)$ \\
Age group 24-29 x Year & $0.03^{* * *}$ & 0.00 & $-0.05^{* * *}$ & 0.03 \\
& $(0.01)$ & $(0.00)$ & $(0.02)$ & $(0.02)$ \\
Constant & $1.46^{* * *}$ & $0.13^{* * *}$ & $-1.34^{* * *}$ & $1.45^{* * *}$ \\
& $(0.04)$ & $(0.02)$ & $(0.08)$ & $(0.12)$ \\
\hline Observations & 10,518 & 10,518 & 6,756 & 5,756 \\
$R^{2}$ & 0.04 & 0.00 & 0.21 & 0.05 \\
\hline
\end{tabular}

Note. Cells report unstandardized OLS regression coefficients with robust standard errors in parentheses. Respondents aged 18-23 is the reference category for age group.

$* \mathrm{p}<0.05, * * \mathrm{p}<0.01, * * * \mathrm{p}<0.001$

We now turn to trends in specific uses of social media, including news use as well as activities conducted over Facebook and Twitter, the two platforms for which we have repeated measures over time. Figure 6 plots mean time spent on social media news use across SES, gender, and age groups, while Table 5 displays the results of the corresponding pooled regressions. The top plot shows a small SES gap in social media news use between 2009 and 2014 that seems to have disappeared by 2015 and reversed by 2018, when those with lower SES appear to use social media for news slightly more often than those with higher SES. These trends are confirmed by the positive, significant coefficients of the interactions of survey year with both lower and middle SES (model 1). The middle and bottom plots also show differences in social media news use between gender and age groups. According to model 2, the significant interaction between gender and survey year means a reversal of the initial gender gap, that is, women increased their news consumption on social media at a higher rate than men. Comparing younger and older respondents, in contrast, yielded a growing gap over time (model 3). The negative significant interaction of age group and year of survey means that college-age increased their reliance on social media for news relative to their older counterparts. 

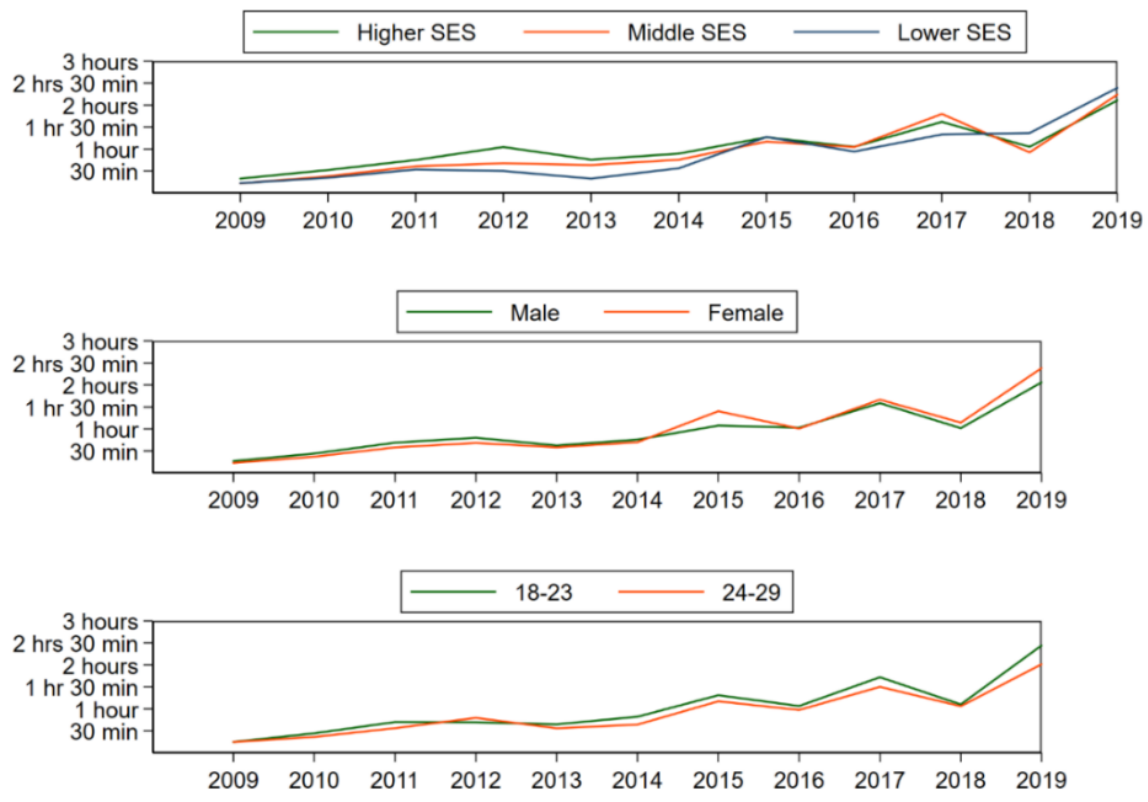

Figure 6: Mean Time Spent on Social Media News Use by SES, Gender and Age Group 
Table 5: Regressions of Social Media News Use by SES, Gender and Age Group

\begin{tabular}{lccc}
\hline & $(1)$ & $(2)$ & $(3)$ \\
& News Use & News Use & News Use \\
\hline Middle SES & $-0.31^{* * *}$ & & \\
Lower SES & $(0.08)$ & & \\
& $-0.38^{* * *}$ & & $0.16^{* * *}$ \\
Year & $(0.08)$ & $0.14^{* * *}$ & $(0.01)$ \\
Middle SES x Year & $0.12^{* * *}$ & $(0.01)$ & \\
Lower SES x Year & $(0.01)$ & & \\
& $0.04^{* *}$ & & \\
Woman & $(0.01)$ & & \\
& $0.04^{*}$ & $-0.17^{* *}$ & $(0.06)$ \\
Woman x Year & $(0.02)$ & $0.03^{* *}$ & 0.02 \\
Age group 24-29 & & $(0.01)$ & $(0.06)$ \\
Age group 24-29 x Year & & & $-0.02^{*}$ \\
Constant & & & $(0.01)$ \\
& & & 0.04 \\
Observations & & $0.13^{* *}$ & $(0.05)$ \\
$R^{2}$ & 10,518 & $(0.04)$ & 10,518 \\
\hline
\end{tabular}

Note. Cells report unstandardized OLS regression coefficients with robust standard errors in parentheses. Reference categories for SES and age group are high SES and aged 18-23, respectively.

$* \mathrm{p}<0.05, * * \mathrm{p}<0.01, * * * \mathrm{p}<0.001$

In the final part of the analysis, we analyzed specific activities conducted over Facebook and Twitter. First, we noted that for linking, chatting, and opinion expression there was a curvilinear, inverted U-shaped trend. Specifically, the proportion of users engaging in these three activities on both platforms peaked between 2013 and 2015 before leveling off. However, in contrast to the noted differences in social media news use, the likelihood of linking, chatting and opinion expression on Facebook and Twitter varied substantially between groups. 
Let us begin with trends in Facebook activities. Although frequency of use of this platform equalized over time between the three SES groups (recall Table 2 above), when it comes to specific activities, significant SES gaps remained (see upper panel of Figure 7). As before, we tested for interactions between groups and survey year, and found that these were statistically significant in the regressions of linking and opinion expression (Table 6, models 1 and 7). The negative sign of the interactions of both lower and middle SES with the linear time trend coupled with the negative sign of the interactions with the quadratic trend mean that higher SES groups engaged more frequently in linking and expressing opinions on Facebook than the rest, although the gap diminished over time. Regarding gender and age groups, we found small — although statistically significant-differences in their likelihood of engaging in any of the Facebook activities considered. For instance, the average difference in the probability of chatting on Facebook between younger and older respondents for the 2009-2019 period — which in the bottom panel of Figure 7 looks like a sizeable gap - amounted to $8.1 \%$ only.

When we repeated the analysis for Twitter activities, we found a similar pattern of results. As shown in Figure 8, we also found a curvilinear time trend, suggesting that Twitter activities were more popular in the middle than at the beginning or end periods under study. Furthermore, we did not find statistically significant interactions between survey year and each of the examined demographic variables when predicting Twitter linking, chatting or opinion expression (see Table 7). The exceptions were weak interactions between lower SES and survey year when providing links and chatting on Twitter, showing that the gap between higher and lower SES closed over time. However, as evident from the top panel in Figure 8, in both cases this was mainly due to higher SES respondents engaging less often in these behaviors than before (instead of lower SES respondents engaging more often with Twitter). 

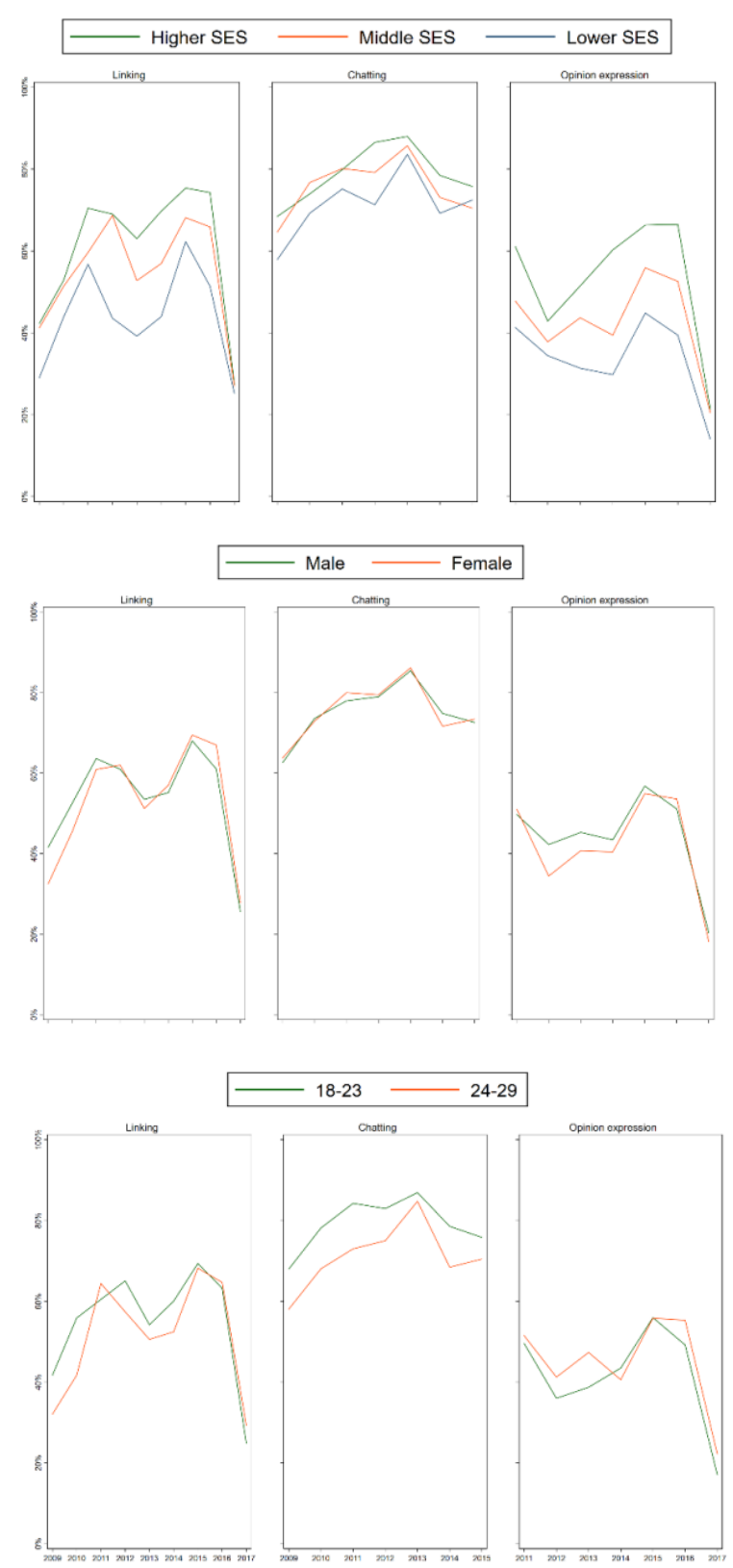

Figure 7: Proportion of Facebook Users who Engage in Activities by SES, Gender, and Age group 
Table 6: Regressions of Likelihood of Linking, Chatting and Opinion Expression in Facebook

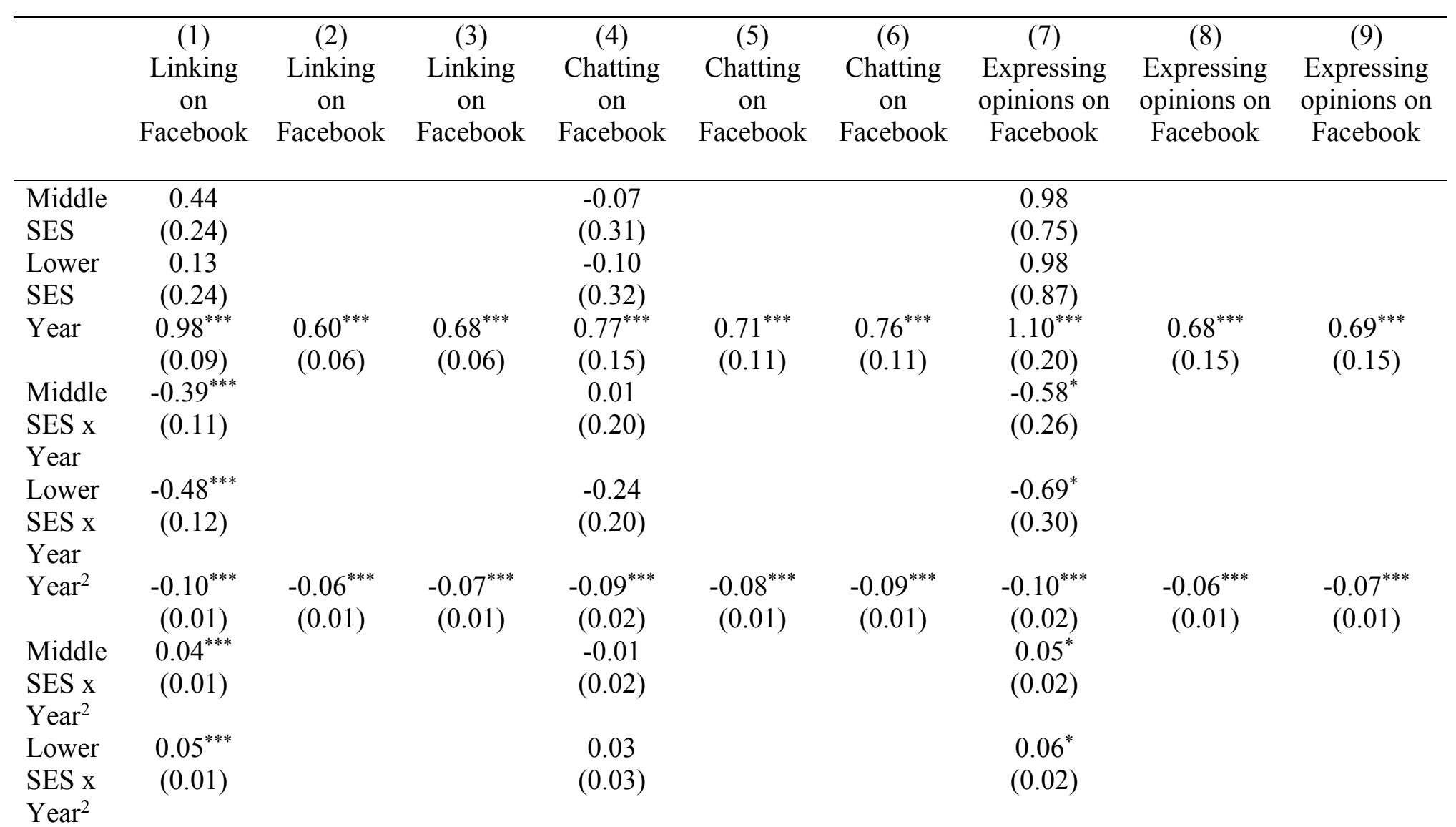




\section{Table 6 (continued)}

\begin{tabular}{|c|c|c|c|c|c|c|c|c|c|}
\hline Woman & & $\begin{array}{c}-0.53^{* *} \\
(0.18)\end{array}$ & & & $\begin{array}{c}0.05 \\
(0.24)\end{array}$ & & & $\begin{array}{c}0.23 \\
(0.64)\end{array}$ & \\
\hline Woman x Year & & $\begin{array}{c}0.15 \\
(0.09)\end{array}$ & & & $\begin{array}{l}-0.00 \\
(0.15)\end{array}$ & & & $\begin{array}{l}-0.14 \\
(0.22)\end{array}$ & \\
\hline Woman x Year ${ }^{2}$ & & $\begin{array}{l}-0.01 \\
(0.01)\end{array}$ & & & $\begin{array}{c}-0.00 \\
(0.02)\end{array}$ & & & $\begin{array}{c}0.01 \\
(0.02)\end{array}$ & \\
\hline $24-29$ & & & $\begin{array}{l}-0.38^{*} \\
(0.19)\end{array}$ & & & $\begin{array}{l}-0.39 \\
(0.24)\end{array}$ & & & $\begin{array}{c}0.58 \\
(0.64)\end{array}$ \\
\hline 24-29 x Year & & & $\begin{array}{l}-0.00 \\
(0.09)\end{array}$ & & & $\begin{array}{l}-0.09 \\
(0.15)\end{array}$ & & & $\begin{array}{l}-0.19 \\
(0.22)\end{array}$ \\
\hline 24-29 x Year² & & & $\begin{array}{c}0.01 \\
(0.01)\end{array}$ & & & $\begin{array}{c}0.01 \\
(0.02)\end{array}$ & & & $\begin{array}{c}0.02 \\
(0.02)\end{array}$ \\
\hline Constant & $\begin{array}{c}-1.35^{* * *} \\
(0.18)\end{array}$ & $\begin{array}{c}-0.88^{* * *} \\
(0.13) \\
\end{array}$ & $\begin{array}{c}-0.96^{* * * *} \\
(0.11)\end{array}$ & $\begin{array}{c}0.00 \\
(0.24)\end{array}$ & $\begin{array}{l}-0.12 \\
(0.17)\end{array}$ & $\begin{array}{c}0.10 \\
(0.16)\end{array}$ & $\begin{array}{c}-2.48^{* * *} \\
(0.58)\end{array}$ & $\begin{array}{c}-1.76^{* * *} \\
(0.43)\end{array}$ & $\begin{array}{c}-1.88^{* * *} \\
(0.42)\end{array}$ \\
\hline Observations & 8,512 & 8,512 & 8,512 & 6,773 & 6,773 & 6,773 & 6,512 & 6,512 & 6,512 \\
\hline Pseudo $R^{2}$ & 0.04 & 0.03 & 0.03 & 0.02 & 0.02 & 0.02 & 0.03 & 0.01 & 0.01 \\
\hline
\end{tabular}

Note. Cells report unstandardized logistic regression coefficients with robust standard errors in parentheses. Reference categories for SES, gender and age group are high SES, man, and aged 18-23, respectively.

${ }^{*} p<0.05,{ }^{* *} p<0.01,{ }^{* * *} p<0.001$ 
Table 7: Regressions of Likelihood of Linking, Chatting and Opinion Expression in Twitter

\begin{tabular}{|c|c|c|c|c|c|c|c|c|c|}
\hline & $\begin{array}{c}(1) \\
\text { Linking } \\
\text { on } \\
\text { Twitter }\end{array}$ & $\begin{array}{c}(2) \\
\text { Linking } \\
\text { on } \\
\text { Twitter }\end{array}$ & $\begin{array}{c}(3) \\
\text { Linking } \\
\text { on } \\
\text { Twitter }\end{array}$ & $\begin{array}{c}(4) \\
\text { Chatting } \\
\text { on } \\
\text { Twitter }\end{array}$ & $\begin{array}{c}(5) \\
\text { Chatting } \\
\text { on } \\
\text { Twitter }\end{array}$ & $\begin{array}{c}(6) \\
\text { Chatting } \\
\text { on } \\
\text { Twitter }\end{array}$ & $\begin{array}{l}(7) \\
\text { Expressing } \\
\text { opinions on } \\
\text { Twitter }\end{array}$ & $\begin{array}{l}\text { (8) } \\
\text { Expressing } \\
\text { opinions on } \\
\text { Twitter }\end{array}$ & $\begin{array}{c}(9) \\
\text { Expressing } \\
\text { opinions on } \\
\text { Twitter }\end{array}$ \\
\hline Middle SES & $\begin{array}{l}-0.03 \\
(0.69)\end{array}$ & & & $\begin{array}{c}0.83 \\
(0.83)\end{array}$ & & & $\begin{array}{c}-0.87 \\
(1.23)\end{array}$ & & \\
\hline Lower SES & $\begin{array}{c}0.62 \\
(0.71)\end{array}$ & & & $\begin{array}{l}2.29^{* *} \\
(0.83)\end{array}$ & & & $\begin{array}{c}0.24 \\
(1.61)\end{array}$ & & \\
\hline Year & $\begin{array}{l}1.05^{* * *} \\
(0.18)\end{array}$ & $\begin{array}{c}0.75^{* * *} \\
(0.14)\end{array}$ & $\begin{array}{c}0.83^{* * *} \\
(0.15)\end{array}$ & $\begin{array}{l}2.03^{* * *} \\
(0.24)\end{array}$ & $\begin{array}{l}1.57^{* * *} \\
(0.17)\end{array}$ & $\begin{array}{l}1.45^{* * *} \\
(0.17)\end{array}$ & $\begin{array}{l}0.72^{*} \\
(0.31)\end{array}$ & $\begin{array}{c}0.35 \\
(0.25)\end{array}$ & $\begin{array}{l}0.91^{* *} \\
(0.28)\end{array}$ \\
\hline $\begin{array}{l}\text { Middle SES x } \\
\text { Year } \\
\text { Lower SES x } \\
\text { Year }\end{array}$ & $\begin{array}{l}-0.31 \\
(0.26) \\
-0.63^{*} \\
(0.28)\end{array}$ & & & $\begin{array}{c}-0.54 \\
(0.32) \\
-1.27^{* * *} \\
(0.33)\end{array}$ & & & $\begin{array}{c}0.02 \\
(0.43) \\
-0.53 \\
(0.56)\end{array}$ & & \\
\hline Year $^{2}$ & $\begin{array}{c}-0.10^{* * * *} \\
(0.02)\end{array}$ & $\begin{array}{c}-0.07^{* * *} \\
(0.01)\end{array}$ & $\begin{array}{c}-0.08^{* * *} \\
(0.01)\end{array}$ & $\begin{array}{c}-0.21^{* * *} \\
(0.02)\end{array}$ & $\begin{array}{c}-0.17^{* * *} \\
(0.01)\end{array}$ & $\begin{array}{c}-0.16^{* * *} \\
(0.02)\end{array}$ & $\begin{array}{c}-0.08^{* *} \\
(0.03)\end{array}$ & $\begin{array}{l}-0.04^{*} \\
(0.02)\end{array}$ & $\begin{array}{c}-0.09^{* * *} \\
(0.02)\end{array}$ \\
\hline $\begin{array}{l}\text { Middle SES x } \\
\text { Year }^{2} \\
\text { Lower SES x } \\
\text { Year }^{2}\end{array}$ & $\begin{array}{c}0.04 \\
(0.02) \\
0.06^{*} \\
(0.03)\end{array}$ & & & $\begin{array}{c}0.05 \\
(0.03) \\
0.12^{* * *} \\
(0.03)\end{array}$ & & & $\begin{array}{c}0.01 \\
(0.03) \\
0.05 \\
(0.05)\end{array}$ & & \\
\hline
\end{tabular}


Table 7 (continued)

\begin{tabular}{|c|c|c|c|c|c|c|c|c|c|}
\hline Woman & & $\begin{array}{c}-0.00 \\
(0.57)\end{array}$ & & & $\begin{array}{c}0.42 \\
(0.66)\end{array}$ & & & $\begin{array}{l}-1.49 \\
(1.14)\end{array}$ & \\
\hline Woman $\mathrm{x}$ & & 0.01 & & & -0.20 & & & 0.46 & \\
\hline Year & & $(0.22)$ & & & $(0.26)$ & & & $(0.39)$ & \\
\hline Woman $\mathrm{x}$ & & -0.00 & & & 0.02 & & & -0.04 & \\
\hline Year $^{2}$ & & $(0.02)$ & & & $(0.02)$ & & & $(0.03)$ & \\
\hline $24-29$ & & & $\begin{array}{c}0.43 \\
(0.56)\end{array}$ & & & $\begin{array}{c}0.03 \\
(0.66)\end{array}$ & & & $\begin{array}{c}2.08 \\
(1.11)\end{array}$ \\
\hline 24-29 x Year & & & $\begin{array}{l}-0.16 \\
(0.22)\end{array}$ & & & $\begin{array}{c}0.04 \\
(0.26)\end{array}$ & & & $\begin{array}{l}-0.69 \\
(0.39)\end{array}$ \\
\hline 24-29 x Year² & & & $\begin{array}{c}0.02 \\
(0.02)\end{array}$ & & & $\begin{array}{l}-0.01 \\
(0.02)\end{array}$ & & & $\begin{array}{c}0.06 \\
(0.03)\end{array}$ \\
\hline Constant & $\begin{array}{c}-3.92^{* * *} \\
(0.47)\end{array}$ & $\begin{array}{c}-3.75^{* * *} \\
(0.38)\end{array}$ & $\begin{array}{c}-3.95^{* * * *} \\
(0.38) \\
\end{array}$ & $\begin{array}{c}-6.07^{* * *} \\
(0.62)\end{array}$ & $\begin{array}{c}-5.29^{* * *} \\
(0.43) \\
\end{array}$ & $\begin{array}{c}-5.10^{* * * *} \\
(0.44)\end{array}$ & $\begin{array}{c}-3.12^{* * *} \\
(0.89) \\
\end{array}$ & $\begin{array}{c}-2.62^{* * *} \\
(0.71)\end{array}$ & $\begin{array}{c}-4.35^{* * *} \\
(0.79)\end{array}$ \\
\hline Observations & 7,512 & 7,512 & 7,512 & 7,512 & 7,512 & 7,512 & 6,512 & 6,512 & 6,512 \\
\hline Pseudo $R^{2}$ & 0.03 & 0.02 & 0.02 & 0.08 & 0.06 & 0.06 & 0.03 & 0.02 & 0.02 \\
\hline
\end{tabular}

Note. Cells report unstandardized logistic regression coefficients with robust standard errors in parentheses. Reference categories for SES, gender and age group are high SES, man, and aged 18-23, respectively.

$* \mathrm{p}<0.05, * * \mathrm{p}<0.01, * * * \mathrm{p}<0.001$ 

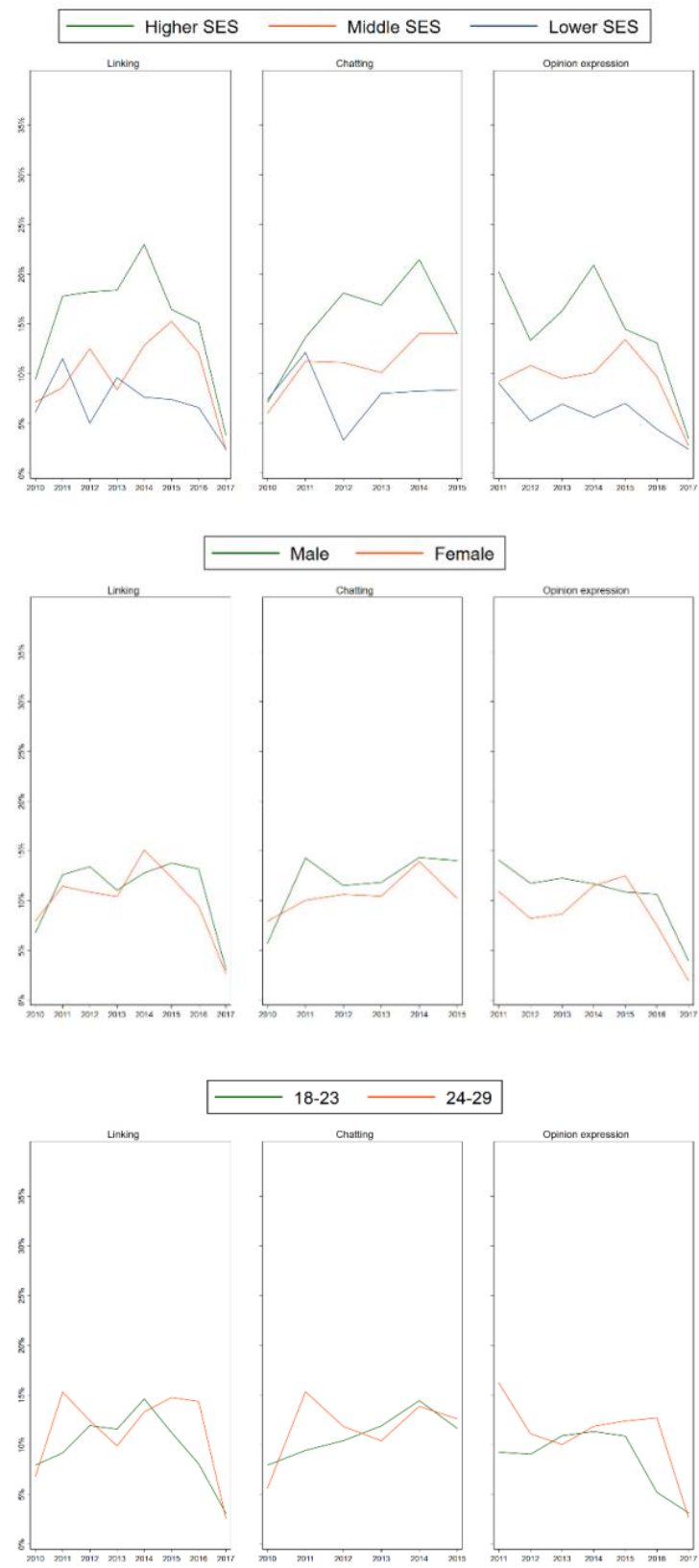

Figure 8: Proportion of Twitter Users who Engage in Activities by SES, Gender, and Age group 


\section{Discussion}

This study investigated how usage of four social media platforms-Facebook, Twitter, Instagram, and WhatsApp — evolved between 2009 and 2019 among urban young adults in Chile. Relying on the Youth, Media and Participation Study - a probability-based survey conducted annually among 1,000 individuals approximately in the 18 to 29 age group - we found that the time spent on television, radio and online media was almost replaced by these social online platforms.

We also found that frequency of use and type of activities conducted over time changed, particularly along socioeconomic status and age. Instead of a uniform trend towards less or more inequality, our results show that each platform shows a unique trend that varied according to the historic context as well. In a first period (2009-2013), Facebook was the leading platform. That changed when WhatsApp and Instagram appeared in the Chilean scenario. While WhatsApp became an almost universal platform for urban youth (with a penetration rate of $96 \%$ ), Instagram showed the steepest growth (from $22 \%$ to $77 \%$ in six years). Twitter, on the other hand, was and remains the least popular platform among urban youth. Rather than evolving in a linear fashion, Twitter use peaked during the most politically agitated periods, such as after the 2011 student and environmental movements. Then, it decreased until it grew again in 2019, which coincided with the so-called "estallido social", when massive demonstrations erupted in several Chilean cities against inequality in economic, social, and political arenas.

When we look at the evolution of frequency of platform usage, we found that Facebook became more equalizing over time in terms of SES, gender, and age. We found that after 2015 there were no major SES- and age-based gaps, whereas the small gender gap at the beginning of the series reversed completely in favor of women by 2014 . However, SES-based inequality remained on WhatsApp and even worsened, albeit weakly, in Instagram and Twitter, where higher-SES youth were increasingly more likely to engage with these platforms than lower-SES young people. Regarding age differences, younger respondents used Instagram more frequently, a gap that also increased over time. There were no remarkable differences by gender across Twitter, Instagram, and WhatsApp. When we 
take a deeper look at the activities conducted and measured on Twitter and Facebook over time, we found significant differences in the likelihood of conducting different activities (e.g., chatting, commenting news, sharing links), especially in socioeconomic terms. Thus, even on platforms such as Facebook where overall frequency of use equalized over time, some behaviors became more stratified.

These results confirm the idea that we need to account for temporal, spatial and technological dynamics when understanding these different social online platforms (Papacharissi, 2015). While research has proposed that people engage with an increasingly diverse media ecology or polymedia (Madianou \& Miller, 2013), in the case of young people in a Latin American country like Chile their repertoire is focusing almost only on social media. Therefore, their communicative and informational opportunities emerge from an "integrated structure" (Madianou \& Miller, 2013) within these online platforms defined by their sociality. That is, the concept of media ecology or polymedia, as it applies to this cohort, is less about the integration of traditional and social media and more about the complementarity of the different social online platforms.

Given the current centrality of online social media, it is necessary to understand their nuances and dynamics. WhatsApp and Facebook are very popular and rather equalizing on their surface, with less SES, gender or age differences in their usage. However, when we look deeper into the activities performed in one of these "equalizing" platforms (Facebook), we find that important socioeconomic differences emerge. Young people are not a monolithic group. They can be almost universally connected but structural inequalities become evident and new usage gaps emerge because the digital inclusion is an evolving process (Correa, 2016; Hargittai, 2010).

Instagram and Twitter's affordances might explain why SES-based gaps have remained across these two platforms, even increasing in the case of Instagram. First, their more public character forces people to expose themselves and their context. In the case of Instagram, people create a filtered online image sharing mostly positive and self-promotional content that focus on leisure, trips and hobbies (Sheldon \& Bryant, 2016), which are highly stratified by SES in Chile. This self-promoting online profile could be more easily created, 
publicly promoted and followed by people who are better off than those who are less welloff (Micheli et al., 2018). This is consistent with research conducted among low SES young people in New York City, which found that participants were aware that their social class limited their freedom and ability to express themselves online. To look "respectable" to the economically privileged audience, those who are perceived as holding the power in these networks, they have to limit their participation and perform a more conservative selfpresentation (Pitcan et al., 2018). Therefore, these gaps might not be explained by differences in digital skills but on the context and social circumstances people are willing to show and see. In turn, Twitter requires to publish short and immediate messages that revolve mostly around public events and news. Therefore, its usage requires language and digital skills as well as an interest in public events, all of which are stratified (Correa, 2016; Contreras \& Puentes, 2017; Somma \& Bargsted, 2018).

Hence, the lower popularity and long-standing socioeconomic gaps of this network comes as no surprise. It is relevant to pay attention to such differences because a vast amount of social media research - particularly that using computational methods and "big data"employs Twitter as a proxy for all social media (Blank \& Lutz, 2017; Hargittai, 2020). This trend analysis shows that the generalizability of this type of research is questionable, especially in countries where it remains the least representative platform of social media use.

The main contribution of this trend analysis is the possibility to describe and understand differences, similarities and the evolution of four major online social platforms using face-to-face representative samples. However, it is not without shortcomings. As any long-term survey projects, detailed measures of social media user are simply not available for all study years. Given that frequency of use is different from specific activities, future research should pay attention to these differences not only on Facebook or Twitter but also WhatsApp - the most popular platform — and Instagram. Also, future research should delve into the socioeconomic stratification of Instagram and its implications given its increasing popularity among young people. It is also interesting to see that there are age differences even among this young group. 
In the current study, we view the coefficients of the age variable as representing age effects (i.e., the biological, psychological and behavioral processes connected with becoming older) and the coefficients of the year variable as representing period effects (i.e., influences specific to a time period that affect all age groups simultaneously) (Yang \& Land, 2013). However, it is possible that the age variable represents cohort effects - the long-lasting influence on social media use of coming of age in, say, 2009-2013, compared to those whose “impressionable years" (Krosnick \& Alwin, 1989) happened between 2015 and 2019. To untangle this relationship and identify generational effects, future research needs to cover a longer timespan than the 11 years of survey data employed here.

Given the differences by platforms, additional studies could investigate how other factors (e.g., self-esteem, different types of skills, social trust, political interest) are associated with different social media platform affordances. Future research should complement selfreported survey data with platform-based data to observe and better describe people's behaviors. Finally, they could conduct panel studies to disentangle whether there are generational or cohort differences, as well as the individual- and contextual-level factors that explain stratification in usage.

\section{Acknowledgments}

Teresa Correa acknowledges the support of ANID grants Fondecyt 1170324 and 1210740 and Prof. Andrés Scherman (School of Communication, Universidad Diego Portales) for leading the data collection and compilation of these annual surveys.

Sebastián Valenzuela acknowledges the support of Millennium Science Initiative Program - ICN17_002 and Prof. Andrés Scherman (School of Communication, Universidad Diego Portales) for leading the data collection and compilation of these annual surveys. 


\section{References}

Blank, G., \& Lutz, C. (2017). Representativeness of social media in Great Britain: Investigating Facebook, Linkedin, Twitter, Pinterest, Google+, and Instagram. American Behavioral Scientist, 61(7), 741-756. https://doi.org/10.1177/0002764217717559

Boczkowski, P. J., Matassi, M., \& Mitchelstein, E. (2018). How young users deal with multiple platforms: The role of meaning-making in social media repertoires. Journal of Computer-Mediated Communication, 23(5), 245-259. https://doi.org/10.1093/jcmc/zmy012

Bucher, T., \& Helmond, A. (2018). The affordances of social media platforms. In J. Burgess, A. Marwick, \& T. Poell (Eds.), The SAGE handbook of social media (pp. 233-253). London: SAGE.

Büchi, M., Just, N., \& Latzer, M. (2016). Modeling the second-level digital divide: A fivecountry study of social differences in Internet use. New Media \& Society, 18(11), 2703-2722. https://doi.org/10.1177/1461444815604154

Contreras, D., \& Puentes, E. (2017). Inequality of opportunities at early ages: Evidence from Chile. The Journal of Development Studies, 53(10), 1748-1764. https://doi.org/10.1080/00220388.2016.1262025

Correa, T. (2016). Digital skills and social media use: how Internet skills are related to different types of Facebook use among 'digital natives'. Information, Communication \& Society, 19(8), 1095-1107. https://doi.org/10.1080/1369118X.2015.1084023

Ellison, N. B., \& Vitak, J. (2015). Social media affordances and their relationship to social capital processes. In S. Sundar (Ed.), The handbook of psychology of communication technology (pp. 205-237). Boston, MA: Wiley-Blackwell.

Ellison, N. B., \& boyd, d. (2013). Sociality through social network sites. In W. Dutton (Ed.) The Oxford handbook of internet studies (pp. 151-172). Oxford, UK: Oxford University Press.

Guess, A., Munger, K., Nagler, J., \& Tucker, J. (2019). How accurate are survey responses on social media and politics? Political Communication, 36(2), 241-258. https://doi.org/10.1080/10584609.2018.1504840

Hargittai, E. (2010). Digital na(t)ives? Variation in Internet skills and uses among members of the 'Net generation'. Sociological Inquiry, 80(1), 92-113. 
https://doi.org/10.1111/j.1475-682X.2009.00317.x

Hargittai, E. (2020). Potential biases in big data: Omitted voices on social media. Social Science Computer Review, 38(1), 10-24. https://doi.org/10.1177/0894439318788322

Hargittai, E., \& Hinnant, A. (2008). Digital inequality: Differences in young adults' use of the Internet. Communication Research, 35(5), 602-621. https://doi.org/10.1177/0093650208321782

Hilbert, M., Vásquez, J., Halpern, D., Valenzuela, S., \& Arriagada, E. (2017). One step, two step, network step? Complementary perspectives on communication flows in Twittered citizen protests. Social Science Computer Review, 35(4), 444-461. https://doi.org/10.1177/0894439316639561

Huang, Y. T., \& Su, S. F. (2018). Motives for Instagram use and topics of interest among young adults. Future Internet, 10(8), 77. https://doi.org/10.3390/fi10080077

INE (Instituto Nacional de Estadísticas) [National Institute of Statistics] (2018).

Urban/rural: Contexto de resultados [Urban/rural: Context of results]. Available at: http://www.censo2017.cl/servicio-de-mapas/descargas/mapas/Urbano-RuralContexto_de_Resultados.pdf

Karapanos, E., Teixeira, P., \& Gouveia, R. (2016). Need fulfillment and experiences on social media: A case on Facebook and WhatsApp. Computers in Human Behavior, 55, 888-897. https://doi.org/10.1016/j.chb.2015.10.015

Krosnick, J., \& Alwin, D. (1989). Aging and susceptibility to attitude change. Journal of Personality and Social Psychology, 57(3), 416-425. https://doi.org/10.1037/0022-3514.57.3.416

Merz, E. C., Wiltshire, C. A., \& Noble, K. G. (2019). Socioeconomic inequality and the developing brain: Spotlight on language and executive function. Child Development Perspectives, 13(1), 15-20. https://doi.org/10.1111/cdep.12305

McCay-Peet, L., \& Quan-Haase, A. (2017). What is social media and what questions can social media research help us answer. In L. Sloan \& A. Quan-Haase (Eds.), The SAGE handbook of social media research methods (pp. 13-26). London: SAGE.

Micheli, M., Lutz, C., \& Büchi, M. (2018). Digital footprints: an emerging dimension of digital inequality. Journal of Information, Communication and Ethics in Society, 16(3), 242-251. https://doi.org/10.1108/JICES-02-2018-0014

Newman, N., Fletcher, R., Schulz, A., Andi, S., \& Nielsen, R. K. (2020). Reuters Institute Digital News Report 2020. Available at: https://reutersinstitute.politics.ox.ac.uk/sites/default/files/2020- 
06/DNR_2020_FINAL.pdf

Norman, D. A. (1998). The invisible computer: Why good products can fail, the personal computer is so complex and information appliances are the solution. Cambridge: The MIT Press.

Open Signal. (2017). Global state of mobile networks. Available at: https://opensignal.com/reports/2017/02/global-state-of-the-mobile-network

Pang, N., \& Woo, Y. T. (2020). What about WhatsApp? A systematic review of WhatsApp and its role in civic and political engagement. First Monday, 25(12), 10417. https://oi.org/10.5210/fm.v25i12.10417

Papacharissi, Z. (2015). We have always been social. Social Media + Society, 1(1). https://doi.org/10.1177/2056305115581185

Pavez, I., \& Correa, T. (2020). "I don't use the internet": Exploring perceptions and practices among mobile-only and hybrid internet users. International Journal of Communication, 14, 19. Retrieved from https://ijoc.org/index.php/ijoc/article/view/12275

Pew Research Center. (2016, February). Smartphone ownership and internet usage continues to climb in emerging economies: Global report. Available at: https://www.pewresearch.org/global/wpcontent/uploads/sites/2/2016/02/pew_resear ch_center_global_technology_report_final_february_22_2016.pdf

Pitcan, M., Marwick, A. E., \& Boyd, D. (2018). Performing a vanilla self: Respectability politics, social class, and the digital world. Journal of Computer-Mediated Communication, 23(3), 163-179. https://doi.org/10.1093/jcmc/zmy008

de Regt, S., van der Lippe, T., \& Jaspers, E. (2020). On the relation between age and the importance attached to historical events. Memory Studies, 13(6), 969-987. https://doi.org/10.1177/1750698018794787

Rojas, E., \& Poveda, L. (2018). Estado de la banda ancha en América Latina y el Caribe [State of broadband in Latin America and the Caribbean]. Santiago, Chile: United Nations Economic Commission for Latin America and the Caribbean.

Rucks, S. (2018). Desiguales. Orígenes, cambios y desafios de la brecha social en Chile [Unequal. Origins, changes and challenges in Chile's social divide]. Santiago, Chile: United Nations Development Programme (UNDP).

Sheldon, P., \& Bryant K. (2016). Instagram: motives for its use and relationship to narcissism and contextual age. Computers in Human Behavior, 58(1): 89-97. https://doi.org/10.1016/j.chb.2015.12.059

Somma, N. M., \& Bargsted, M. A. (2018). Political inequality in 38 countries: A 
distributional approach. Comparative Sociology, 17(5), 469-495.

https://doi.org/10.1163/15691330-12341475

Subtel. (2017, December). IX encuesta de acceso y usos de Internet [Ninth survey of internet access and uses]. Available at:

https://www.subtel.gob.cl/wpcontent/uploads/2018/07/Informe_Final_IX_Encuesta Acceso_y_Usos_Internet_2017.pdf

Treem, J. W., \& Leonardi, P. M. (2013). Social media use in organizations: Exploring the affordances of visibility, editability, persistence, and association. Annals of the International Communication Association, 36, 143-189.

https://doi.org/10.1080/23808985.2013.11679130

Valenzuela, S., Correa, T., \& Gil de Zúñiga, H. (2018). Ties, likes, and tweets: Using strong and weak ties to explain differences in protest participation across Facebook and Twitter use. Political Communication, 35(1), 117-134. https://doi.org/10.1080/10584609.2017.1334726

Van Deursen, A. J., Van Dijk, J. A., \& Peter, M. (2015). Increasing inequalities in what we do online: A longitudinal cross-sectional analysis of Internet activities among the Dutch population (2010 to 2013) over gender, age, education, and income. Telematics and Informatics, 32(2), 259-272. https://doi.org/10.1016/j.tele.2014.09.003

Waterloo, S. F., Baumgartner, S. E., Peter, J., \& Valkenburg, P. M. (2018). Norms of online expressions of emotion: Comparing Facebook, Twitter, Instagram, and WhatsApp. New Media \& Society, 20(5), 1813-1831. https://doi.org/10.1177/1461444817707349

Wooldridge, J. M. (2001). Econometric analysis of cross section and panel data. Cambridge, MA: The MIT Press.

World Bank. (2021). Gini Index. Available at https://data.worldbank.org/indicator/SI.POV.GINI?locations $=\mathrm{CL}$

Yang, Y. \& Land, K. (2013). Age-period-cohort analysis: new models, methods, and empirical applications. New York: Chapman \& Hall/CRC. 


\section{Appendix}

Table A1: Distribution of Sociodemographic Variables

\begin{tabular}{|c|c|c|c|c|c|c|c|c|c|c|c|}
\hline & $\begin{array}{c}2009 \\
\%\end{array}$ & $\begin{array}{c}2010 \\
\%\end{array}$ & $\begin{array}{c}2011 \\
\%\end{array}$ & $\begin{array}{c}2012 \\
\%\end{array}$ & $\begin{array}{c}2013 \\
\%\end{array}$ & $\begin{array}{c}2014 \\
\%\end{array}$ & $\begin{array}{c}2015 \\
\%\end{array}$ & $\begin{array}{c}2016 \\
\%\end{array}$ & $\begin{array}{c}2017 \\
\%\end{array}$ & $\begin{array}{c}2018 \\
\%\end{array}$ & $\begin{array}{c}2019 \\
\%\end{array}$ \\
\hline \multicolumn{12}{|l|}{ SES } \\
\hline Higher SES & 25.8 & 26.1 & 30.2 & 31.7 & 20.9 & 28.1 & 35.1 & 23.9 & 35.5 & 47.3 & 36.8 \\
\hline Middle SES & 38.0 & 36.9 & 48.0 & 39.2 & 60.4 & 37.5 & 31.5 & 49.1 & 41.5 & 30.9 & 43.3 \\
\hline Lower SES & 36.2 & 37.0 & 21.8 & 29.1 & 18.7 & 34.4 & 33.4 & 27.1 & 23.0 & 21.9 & 20.0 \\
\hline \multicolumn{12}{|l|}{ Gender } \\
\hline Woman & 50.3 & 49.6 & 49.2 & 50.0 & 49.4 & 49.4 & 49.5 & 49.5 & 49.2 & 49.3 & 49.6 \\
\hline Man & 49.7 & 50.4 & 50.8 & 50.0 & 50.6 & 50.6 & 50.5 & 50.5 & 50.8 & 50.7 & 50.4 \\
\hline \multicolumn{12}{|l|}{ Age group } \\
\hline $18-23$ & 51.6 & 53.3 & 53.5 & 50.0 & 48.0 & 47.8 & 48.2 & 57.1 & 48.0 & 47.8 & 50.6 \\
\hline $24-29$ & 48.4 & 46.7 & 46.5 & 50.0 & 52.0 & 52.2 & 51.8 & 42.9 & 52.0 & 52.2 & 49.4 \\
\hline
\end{tabular}


Table A2: Distribution of Social Media Access and Frequency of Use

\begin{tabular}{|c|c|c|c|c|c|c|c|c|c|c|c|}
\hline & $\begin{array}{c}2009 \\
\%\end{array}$ & $\begin{array}{c}2010 \\
\%\end{array}$ & $\begin{array}{c}2011 \\
\% \\
\end{array}$ & $\begin{array}{c}2012 \\
\%\end{array}$ & $\begin{array}{c}2013 \\
\%\end{array}$ & $\begin{array}{c}2014 \\
\% \\
\end{array}$ & $\begin{array}{c}2015 \\
\%\end{array}$ & $\begin{array}{c}2016 \\
\%\end{array}$ & $\begin{array}{c}2017 \\
\%\end{array}$ & $\begin{array}{c}2018 \\
\%\end{array}$ & $\begin{array}{c}2019 \\
\%\end{array}$ \\
\hline \multicolumn{12}{|l|}{ Registered users } \\
\hline Facebook & 73.1 & 84.8 & 86.3 & 87.0 & 93.7 & 90.7 & 93.0 & 94.3 & 80.5 & 85.8 & 86.0 \\
\hline Twitter & 4.4 & 15.2 & 20.6 & 26.4 & 24.7 & 20.9 & 18.4 & 17.3 & 13.2 & 13.7 & 21.3 \\
\hline Instagram & & & & & 22.5 & 29.5 & 41.5 & 52.8 & 56.0 & 66.7 & 77.3 \\
\hline WhatsApp & & & & & & 84.2 & 90.9 & 95.4 & 91.6 & 96.4 & 96.0 \\
\hline \multicolumn{12}{|c|}{ Frequency of use Facebook } \\
\hline Never & 24.4 & 15.4 & 14.8 & 16.3 & 9.5 & 15.1 & 8.9 & 10.7 & 20.1 & 15.2 & 14.0 \\
\hline Once a month or less & 4.2 & 3.6 & 2.2 & 2.6 & 2.3 & 1.5 & 1.0 & 0.8 & 0.8 & 1.3 & 0.9 \\
\hline 2 or 3 times a month & 1.9 & 2.7 & 1.8 & 1.4 & 1.9 & 1.5 & 1.6 & 1.1 & 1.0 & 0.9 & 0.6 \\
\hline 1 to 6 days a week & 21.8 & 27.7 & 23.4 & 19.7 & 16.7 & 10.7 & 13.3 & 13.6 & 8.6 & 15.0 & 15.6 \\
\hline Once a day & 17.1 & 18.7 & 23.5 & 21.3 & 22.9 & 13.0 & 12.5 & 15.9 & 11.1 & 11.2 & 11.6 \\
\hline Several times a day & 30.5 & 32 & 34.2 & 38.7 & 46.8 & 58.1 & 62.7 & 57.8 & 58.4 & 56.5 & 57.3 \\
\hline \multicolumn{12}{|l|}{ Frequency of use Twitter } \\
\hline Never & 79.4 & 85 & 80.4 & 76.0 & 76.0 & 80.1 & 82.4 & 84.5 & 87.1 & 86.3 & 79 \\
\hline Once a month or less & 13.7 & 2.2 & 2.6 & 5.0 & 5.6 & 3.2 & 3.7 & 2.7 & 1.9 & 1.1 & 0.7 \\
\hline 2 or 3 times a month & 2.8 & 1.2 & 1.5 & 1.5 & 2.3 & 2.2 & 1.4 & 0.9 & 0.8 & 0.8 & 0.6 \\
\hline 1 to 6 days a week & 2.0 & 5.7 & 8.0 & 9.3 & 8.7 & 6.9 & 6.1 & 5.6 & 3.9 & 6.1 & 6.7 \\
\hline Once a day & 0.4 & 2.6 & 4.0 & 3.7 & 3.8 & 2.6 & 4.0 & 3.5 & 1.9 & 0.8 & 2.4 \\
\hline Several times a day & 1.7 & 3.2 & 3.6 & 4.6 & 3.6 & 5.0 & 2.5 & 2.9 & 4.3 & 4.9 & 10.6 \\
\hline
\end{tabular}




\section{Table A2 (continued)}

\begin{tabular}{|c|c|c|c|c|c|c|c|}
\hline \multicolumn{8}{|c|}{ Frequency of use Instagram } \\
\hline Never & 78.5 & 72.1 & 59.0 & 48.9 & 44.9 & 34.0 & 23.0 \\
\hline Once a month or less & 2.5 & 3.2 & 3.7 & 1.6 & 0.5 & 0.4 & 0.4 \\
\hline 2 or 3 times a month & 1.7 & 1.9 & 1.1 & 3.4 & 1.2 & 1.0 & 0.7 \\
\hline 1 to 6 days a week & 9.1 & 9.1 & 13.1 & 13 & 7.6 & 9.9 & 8.7 \\
\hline Once a day & 4.1 & 2.3 & 7.6 & 11.2 & 7.3 & 6.6 & 8.2 \\
\hline Several times a day & 4.1 & 11.4 & 15.4 & 21.8 & 38.4 & 48.0 & 59.0 \\
\hline \multicolumn{8}{|c|}{ Frequency of use WhatsApp } \\
\hline Never & & 19.6 & 12.0 & 7.1 & 9.4 & 4.1 & 4.0 \\
\hline Once a month or less & & 2.3 & 0.6 & 0.5 & 0.1 & 0.1 & 0.0 \\
\hline 2 or 3 times a month & & 1.3 & 0.8 & 1.5 & 0.1 & 0.0 & 0.5 \\
\hline 1 to 6 days a week & & 3.6 & 5.9 & 8.7 & 3.5 & 1.6 & 1.4 \\
\hline Once a day & & 6.7 & 8.8 & 14.4 & 5.5 & 5.3 & 6.4 \\
\hline Several times a day & & 66.5 & 71.9 & 67.7 & 81.4 & 89.0 & 87.7 \\
\hline
\end{tabular}


Table A3: Distribution of Social Media Activities

\begin{tabular}{|c|c|c|c|c|c|c|c|c|c|c|c|}
\hline & $\begin{array}{c}2009 \\
\% \\
\end{array}$ & $\begin{array}{c}2010 \\
\% \\
\end{array}$ & $\begin{array}{c}2011 \\
\% \\
\end{array}$ & $\begin{array}{c}2012 \\
\% \\
\end{array}$ & $\begin{array}{c}2013 \\
\% \\
\end{array}$ & $\begin{array}{c}2014 \\
\% \\
\end{array}$ & $\begin{array}{c}2015 \\
\% \\
\end{array}$ & $\begin{array}{c}2016 \\
\% \\
\end{array}$ & $\begin{array}{c}2017 \\
\% \\
\end{array}$ & $\begin{array}{c}2018 \\
\% \\
\end{array}$ & $\begin{array}{c}2019 \\
\% \\
\end{array}$ \\
\hline \multicolumn{12}{|l|}{ Social media news use } \\
\hline None & 78.8 & 69.4 & 58.2 & 62.3 & 63.0 & 56.8 & 45.1 & 38.5 & 36.3 & 44.5 & 23.1 \\
\hline $1 \mathrm{hr}$ a day & 19.1 & 24.8 & 32.7 & 25.6 & 26.4 & 31.4 & 35.1 & 45.0 & 29.1 & 34.8 & 27.7 \\
\hline 2 hrs a day & 1.5 & 3.6 & 3.7 & 4.6 & 7.5 & 6.3 & 7.0 & 8.9 & 11.9 & 9.1 & 17.9 \\
\hline 3 hrs a day & 0.2 & 1.3 & 2.4 & 3.0 & 1.3 & 1.4 & 4.1 & 3.6 & 8.2 & 4.4 & 10.9 \\
\hline 4 hrs a day & 0.3 & 0.5 & 0.9 & 0.8 & 0.5 & 1.9 & 2.0 & 1.0 & 4.4 & 2.9 & 4.8 \\
\hline 5 or more hrs a day & 0.2 & 0.4 & 2.1 & 3.7 & 1.3 & 2.2 & 6.7 & 3.1 & 10.0 & 4.3 & 15.6 \\
\hline \multicolumn{12}{|l|}{ Activities on Facebook } \\
\hline Linking & 37.0 & 49.0 & 62.3 & 61.5 & 52.4 & 56.1 & 68.7 & 64.0 & 26.7 & & \\
\hline Chatting & 63.1 & 73.2 & 79.0 & 79.2 & 85.8 & 73.3 & 73.0 & & & & \\
\hline Expressing opinions & & & 50.4 & 38.4 & 43.0 & 42.0 & 55.9 & 52.3 & 19.3 & & \\
\hline \multicolumn{12}{|l|}{ Activities on Twitter } \\
\hline Linking & & 7.4 & 12.0 & 12.2 & 10.7 & 13.9 & 13.1 & 11.3 & 2.9 & & \\
\hline Chatting & & 6.8 & 12.2 & 11.1 & 11.1 & 14.1 & 12.1 & 0.0 & 0.0 & & \\
\hline Expressing opinions & & & 12.5 & 10.0 & 10.5 & 11.6 & 11.7 & 9.1 & 2.9 & & \\
\hline
\end{tabular}




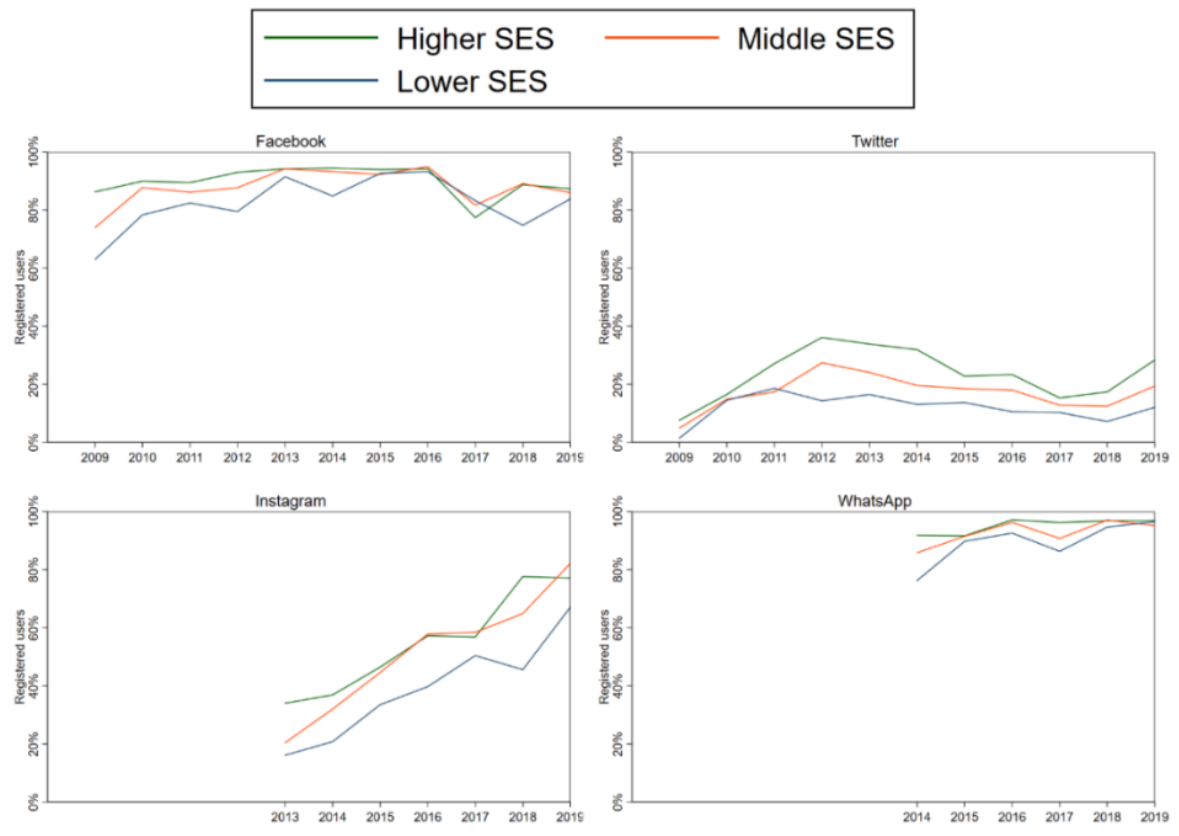

Figure B1: Registered Users of Social Media by SES 
Table B1: Regressions of Social Media Penetration by SES

\begin{tabular}{lcccc}
\hline & $\begin{array}{c}(1) \\
\text { Facebook }\end{array}$ & $\begin{array}{c}(2) \\
\text { Twitter }\end{array}$ & $\begin{array}{c}(3) \\
\text { Instagram }\end{array}$ & $\begin{array}{c}(4) \\
\text { WhatsApp }\end{array}$ \\
\hline \multirow{3}{*}{ Middle SES } & & & & \\
& $-0.71^{* *}$ & $-0.41^{* *}$ & $-0.78^{*}$ & -0.33 \\
Lower SES & $(0.22)$ & $(0.15)$ & $(0.32)$ & $(0.83)$ \\
& $-1.46^{* * *}$ & $-0.85^{* * *}$ & -0.71 & $-1.68^{*}$ \\
Year & $(0.21)$ & $(0.17)$ & $(0.36)$ & $(0.81)$ \\
& -0.04 & 0.00 & $0.35^{* * *}$ & $0.25^{* *}$ \\
Middle SES x Year & $(0.02)$ & $(0.01)$ & $(0.03)$ & $(0.08)$ \\
& $0.09^{* *}$ & 0.01 & $0.08^{*}$ & -0.01 \\
Lower SES x Year & $(0.03)$ & $(0.02)$ & $(0.04)$ & $(0.10)$ \\
& $0.15^{* * *}$ & 0.01 & -0.00 & 0.11 \\
Constant & $(0.03)$ & $(0.02)$ & $(0.04)$ & $(0.10)$ \\
& $2.42^{* * *}$ & $-1.22^{* * *}$ & $-2.59^{* * *}$ & 0.88 \\
Observations & $(0.17)$ & $(0.11)$ & $(0.25)$ & $(0.66)$ \\
Pseudo $R^{2}$ & 10,518 & 10,518 & 6,756 & 5,756 \\
\hline
\end{tabular}

Note. Cells report unstandardized logistic regression coefficients with robust standard errors in parentheses. Higher SES is the reference category for SES.

$* \mathrm{p}<0.05,{ }^{* *} \mathrm{p}<0.01, * * * \mathrm{p}<0.001$ 


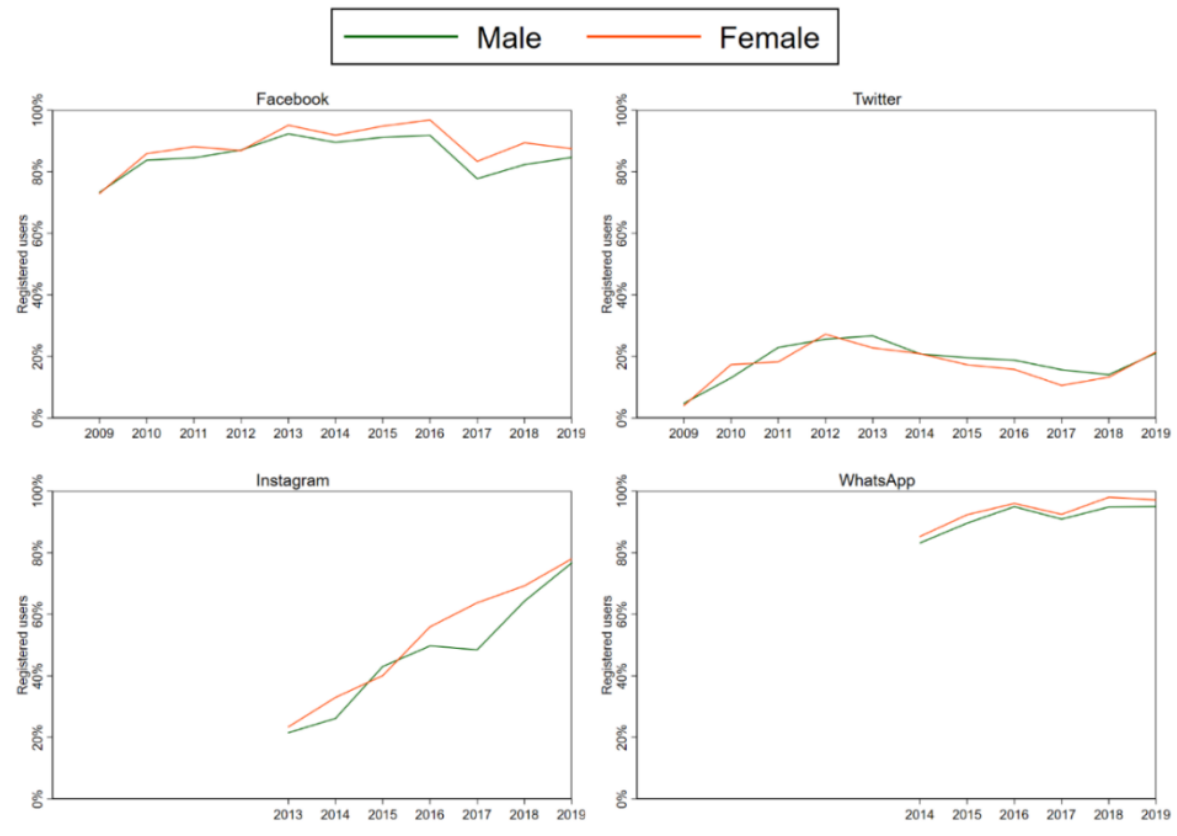

Figure B2: Registered Users of Social Media by Gender

Table B2: Regressions of Social Media Penetration by Gender

\begin{tabular}{lcccc}
\hline & $(1)$ & $(2)$ & $(3)$ & $(4)$ \\
& Facebook & Twitter & Instagram & WhatsApp \\
\hline \multirow{2}{*}{ Woman } & & & & \\
& -0.04 & -0.02 & 0.04 & -0.50 \\
Year & $(0.15)$ & $(0.13)$ & $(0.27)$ & $(0.62)$ \\
& 0.03 & $0.03^{*}$ & $0.38^{* * *}$ & $0.27^{* * *}$ \\
Woman x Year & $(0.02)$ & $(0.01)$ & $(0.02)$ & $(0.05)$ \\
& $0.06^{*}$ & -0.01 & 0.02 & 0.11 \\
Constant & $(0.02)$ & $(0.02)$ & $(0.03)$ & $(0.08)$ \\
& $1.59^{* * *}$ & $-1.64^{* * *}$ & $-3.20^{* * *}$ & 0.18 \\
Observations & $(0.11)$ & $(0.09)$ & $(0.19)$ & $(0.40)$ \\
Pseudo $R^{2}$ & 10,518 & 10,518 & 6,756 & 5,756 \\
\hline
\end{tabular}

Note. Cells report unstandardized logistic regression coefficients with robust standard errors in parentheses.

$* \mathrm{p}<0.05, * * \mathrm{p}<0.01, * * * \mathrm{p}<0.001$ 


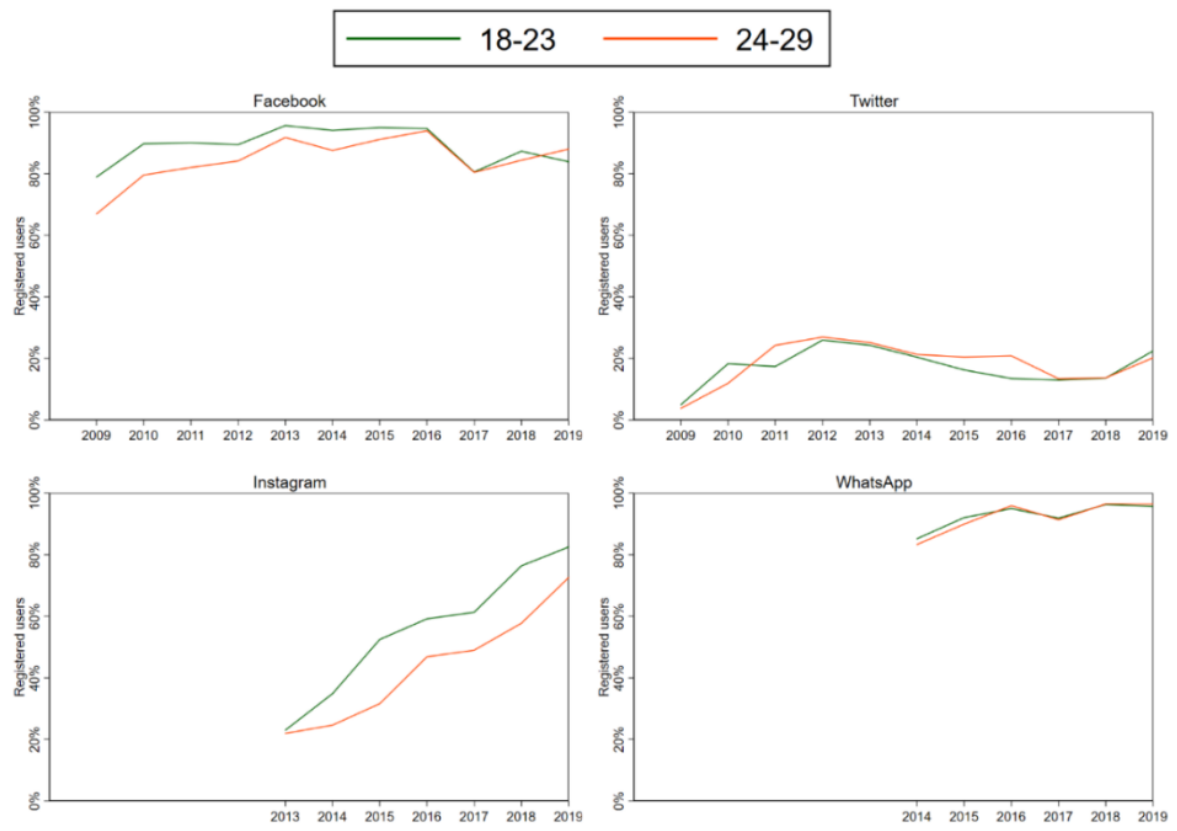

Figure B3: Registered Users of Social Media by Age Group 
Table B3: Regressions of Social Media Penetration by Age Group

\begin{tabular}{lcccc}
\hline & $\begin{array}{c}(1) \\
\text { Facebook }\end{array}$ & $\begin{array}{c}(2) \\
\text { Twitter }\end{array}$ & $\begin{array}{c}(3) \\
\text { Instagram }\end{array}$ & $\begin{array}{c}(4) \\
\text { WhatsApp }\end{array}$ \\
\hline & & & & \\
Age group 24-29 & $-0.96^{* * *}$ & 0.01 & -0.07 & -0.66 \\
& $(0.15)$ & $(0.13)$ & $(0.27)$ & $(0.61)$ \\
Year & -0.00 & 0.01 & $0.43^{* * *}$ & $0.27^{* * *}$ \\
& $(0.02)$ & $(0.01)$ & $(0.02)$ & $(0.05)$ \\
Age group 24-29 x & $0.10^{* * *}$ & 0.01 & -0.06 & 0.08 \\
Year & $(0.02)$ & $(0.02)$ & $(0.03)$ & $(0.08)$ \\
Constant & $2.11^{* * *}$ & $-1.65^{* * *}$ & $-3.19^{* * *}$ & 0.33 \\
& $(0.11)$ & $(0.08)$ & $(0.18)$ & $(0.42)$ \\
\hline Observations & 10,518 & 10,518 & 6,756 & 5,756 \\
Pseudo $R^{2}$ & 0.01 & 0.00 & 0.11 & 0.03 \\
\hline Note. Cells report unstandardized logistic regression coefficients with robust standard errors \\
in parentheses. Respondents aged 18-23 is the reference category for age group. \\
$* \mathrm{p}<0.05, * * \mathrm{p}<0.01, * * * \mathrm{p}<0.001$ & \multicolumn{3}{l}{}
\end{tabular}

